Dinh TRAN NGOC HUY

Banking University, HCMC, Viet Nam - Graduate School of International Management, International University of Japan, Niigata, Japan

\title{
THE CRITICAL THINKING OF SOME WESTERN EUROPEAN CORPORATE GOVERNANCE STANDARDS AFTER FINANCIAL CRISIS, CORPORATE SCANDALS AND MANIPULATION
}

Case study

\author{
Keywords \\ Corporate governance standards \\ Board structure \\ Code of best practice \\ Financial crisis \\ Corporate scandals \\ Market manipulation \\ Internal audit \\ JEL Classification \\ G30
}

\begin{abstract}
After the recent global crisis, corporate scandals and bankruptcy in US and Europe, there is some certain evidence on weak auditing, risk management, accounting and audit system. This paper chooses a different analytical approach and among its aims is to give some systematic opinions on corporate governance criteria as a benchmark for stock markets.

Firstly, it classifies limited Western European representative corporate governance $(C G)$ standards into two (2) groups: The Netherlands and Belgium latest CG principles covered in group 1 and, group 2, including corporate governance principles from Italy and Austria, socalled relative good CG group, while it uses OECD and ICGN principles as reference. Secondly, it identifies through analysis the differences and advantages between the above set of standards which are and have been used as reference principles for many relevant organizations.

Third, it establishes a selected comparative set of standards for Western European representative corporate governance system in accordance to international standards. Last but not least, this paper covers some ideas and policy suggestions.
\end{abstract}




\section{Introduction}

After corporate scandals happening during and after global monetary and financial crises, it is necessary to re-evaluate the code of corporate governance. In reality, many nations re-issue their principles of corporate governance as guidelines for their market and companies. This paper selects an easy-reading writing style, and it finds out that there are still some academic words that need to be explained in further.

The organization of paper contents is organized as following. As our previous series of paper, Research literature and theories are covered in the first two sessions. Next, it is followed by introduction of our research methodology in session $3\left(3^{\text {rd }}\right)$. Continuously, session four (4) covers our familiar four (4) groups of empirical findings. And our conclusion and policy suggestion is covered in the fifth $\left(5^{\text {th }}\right)$ session. Before last, there is an exhibit session which covers some summary of this paper's analysis and comparison. And lastly, a glossary note is provided with information for reference and because of reducing repeating terminology.

\section{Body of Manuscript}

\section{Research literature review}

There are many and controversial opinions on corporate governance theories and practices. For example, Jensen and Meckling (1976) presented their conceptual agency theory on the separation of ownership and management. Belgian Code 2009 stated that corporate governance is a set of rules and behaviours which determine how companies are managed and controlled.

Besides, Thailand 2006 Code defines CG as a set of structures and processes of the relationship between a firm's board of directors, its MGT and its shareholders to boost the firm's competitiveness, growth and long-term shareholder value taking into account the interests of other stakeholders. Malaysian Code on CG 2012 defines $\mathrm{CG}$ as the process and structure used to direct and manage the business and affairs of the company towards enhancing business prosperity and corporate accountability with the ultimate objective of realizing long-term shareholder value.

Additionally, Berger et al (2013) found out that during the financial crisis, bank defaults are strongly influenced by a bank's ownership structure.

Generally, CG refers to the set of systems, processes and structures in which the company is governed.

Because there are not many researches and surveys done in Western European region on CG, next, what is the limited comparative standardized set of so-called comparative Western European corporate governance standards?

Theory of Corporate Governance, Scandal and Market Manipulation

\section{Theory of manipulation}

Market manipulation covers errors in the interfering of the market operation and creates false information on price or market for a financial commodity such as stock.

Aggarwal and Wu (2003) suggested a strong role for government regulation to discourage manipulation while encouraging greater competition for information. And more illiquid stocks are more likely to be manipulated and manipulation increases stock volatility. Imisiker and Tas (2011) presented from Istanbul stock exchange, small firms, firms with less free float rate and a higher leverage ratio are more prone to stock price manipulation.

\section{Theory of corporate governance and financial crisis}

In 2008, OECD also stated that the financial crisis revealed severe shortcomings in corporate governance.

Winter (2011) pointed that after the governance crisis 2001-2003 and the regulatory response through the Sarbanes 
Oxley Act and the European CG codes, the financial crisis has revealed persistent governance problems in financial institutions relating to executives, non executives and shareholders. Also, Ezzine and Olivero (2013) found out that effective governance mechanisms enhance the ability of firms to absorb a stock market crisis. Guota et al (2013) pointed that there is the lack of significant impact of corporate governance quality on performance. And well governed firms do not outperform poorly governed firms.

Hence, we can see, there exist various views on corporate governance and its importance.

\section{Research methodology}

Firstly, we analyze and compare corporate governance principles in each of the two (2) different groups including: 1) Group 1 - Limited Western European CG representative standards including Belgian Code 2009 and The Netherlands Corporate Governance Principles; and 2) Group 2 Relatively good corporate governance group including Italian Code and Austrian CG principles;

Secondly, we also use international standards of corporate governance such as: ICGN and OECD Corporate Governance Principles and Enhancing Banking CG Code 1999 which have many modifications in corporate governance principles after the crisis period.

Then, we propose what so-called limited comparative Western European corporate governance principles which are aiming to create a basic background for relevant corporations interesting in different aspects of corporate governance subjects and functions as the recommendation to relevant countries' government and other relevant organizations for public policy and necessary evaluation.

Last but not least, for a summary of our standards, see Exhibit and the below table 1 and 2 in relevant sessions.

\section{Empirical findings}

A- Findings on Corporate governance issues after financial crisis, corporate scandals and market manipulation

Some certain popular issues include: the roles and duties of CEO and senior management.

Also, we can find out another corporate governance (CG) issue, it is the lack of descriptions of an effective risk management system.

\section{B- Findings on Ways of Manipulation during Corporate Scandals}

Several Manipulation Techniques were found out during corporate scandals, but not limited to:

\section{B.1 - The manipulation techniques in the income statement:}

In Waste Management Scandal (1998), a Houston publicly traded waste management firm, there is a report of $\$ 1.7$ $\mathrm{b}$ in fake income.

\section{B.2 - The manipulation techniques in} both the income statement and balance sheet:

In the case of Refco financial service company, based in New York, entered the crisis and Chapter 11 in 2005 when its CEO had concealed $\$ 430 \mathrm{~b}$ in bad debts.

\section{B.3 - The manipulation techniques relevant to international accounting practice code:}

In the scandal case of Global Crossing Ltd., a telecommunication firm, there is a failure in using international accounting standards (GAAP) in making financial reports. The company did not fairly present financial statements.

\section{B.4 - Other manipulation techniques net belong to above classifications: \\ In some scandals, there is management manipulation which causes the loss of investments. In the case of Worldcom, a telecomm scandal, directors have used false accounting methods to manipulate stock prices after falling.}




\section{C- Actions on Preventing or Controlling negative manipulation}

Among necessary actions to control negative market manipulation are, but not limited to, the mechanism of the board and its committees aiming to increase effectiveness and transparency with investors. Accounting and financial reporting process are also taken into account.

\section{D- Findings on Construction of Comparative Western European Corporate Governance Standards}

These findings will be shown in a detailed analysis of a model indicated in the later sessions.

<D.1> - Group 1 - Limited Western European Corporate Governance standards analysis

\section{The Belgium Code of Corporate Governance 2009}

The Belgian Code 2009 has been modified from its first version in 2004.

Among its advantages are, but not limited to, $\mathrm{CG}$ charter and $\mathrm{CG}$ statement. $\mathrm{CG}$ statement of the annual report covers a description of operation of committees, whereas $\mathrm{CG}$ charter includes direct or indirect relationship of the firm and major shareholders.

Generally speaking, The Code focuses on Board, Committees and disclosure of remuneration policy of executive managers mentioned in the $\mathrm{CG}$ statement. (see Exhibit 1).

\section{The Netherlands Corporate Governance Principles}

The Netherlands Best practices 2006 cover some major CG matters such as board roles and risk management.

Different from other European Codes, one of its distinctions is clarifying roles of supervisory board (SB). For example, SB should meet regularly and retain effective control over the firm.
For more information, please see Exhibit 2. However, it would be better to mention guidelines of CEO roles.

Comparison between the Belgian and the Netherlands Corporate Governance Principles

A lot of information on roles of Board is in the Belgian Code 2009. For example, it is pointed that the Board ensures the integrity and timely disclosure of the firm F.S, but it would be better to give guidelines for a compliance officer. (see Exhibit 1).

On the other hand, the Netherlands Code stated roles of SB in ensuring appropriate plans and policies for the firm. Besides, it also oversees business performance.

\section{<D.2〉 -Group 2 - Relative Good Corporate governance group analysis}

\section{Italian 2002 Corporate Governance standards analysis:}

Good recommendations involved the description of IC system. For example, the firm appoints a person who runs the IC system and report to IC committee, MD, board of auditors.

Besides, it makes a sound point to suggest that IC committee reports to BD every 6 months on the adequacy of the IC system.

A minor point that might be noted here is that it does not describe well the roles of compliance officer; please refer to the Exhibit 3.

In summary, the 2002 Code and supported documents paid well attention to Board and IC committee.

Austrian Code of Corporate Governance standards analysis:

In the 2012 Code, we recognized that it pays attention to Supervisory Board roles. For example, the SB needs at least 3 members. And it also mentions disclosure of fixed and variable remuneration for each individual of MGT board and SB.

And among its advantages is that it mentions general information on GM published on website. Please refer to Exhibit 4. 
On the other hand, it has a disadvantage as it does not describe well CEO roles.

\section{Comparison between the Italian and Austrian Corporate Governance Principles}

First of all, there is a focus in the 2012 Austrian CG Code setting itself a benchmark for corporations. Moreover, it states roles of $\mathrm{SB}$ and criteria for SB members such as professional experience and independence.

Beside, The Italian Code of Good Corporate Governance 2006 pointed that the Board is in charge of examining transactions with significant impacts on profits, assets and liabilities. It also makes good points of the board role in verifying controls to monitor performance of the firm.

The $1^{\text {st }}$ Establishment of so-called relatively Good Corporate Governance standards

This following table is built with the summary of above Commonwealth CG standards.

\section{D.3- The $1^{\text {st }}$ Establishment of so-called limited comparative Western European Corporate Governance standards Comparison of corporate governance standards between $\langle\mathrm{D} .1\rangle$ and $\langle\mathrm{D} .2\rangle$ group}

Before we come to set up a set of general limited standards of corporate governance, we need to review the standards combined in the previous two (2) groups

The advantages of Group 1 consist of, but not limited to, the roles of $\mathrm{AC}$ in reviewing the relevance of accounting standards used by firm (see Table 1 and 2). On the contrary, the relative Good Corporate Governance Group standard states well and focuses on the role of Supervisory board (SB). For example, it also mentions w/o SB approval, MGT board member cannot run a business (see 2012 Austrian Code). Last but not least, Italian Code presents the role of $\mathrm{GM}$ as the meeting to provide shareholders with information while complying with the procedure relating price-sensitive information.

A so-called Limited Comparative Western European Corporate Governance Set of standards

Based on the above analysis, we consider building comparative standards for a comparative Western European Corporate Governance system.

\section{Conclusion}

To overcome weaknesses from CG during crises, The Belgian Code 2009 suggested Board roles are important skills, the experience and knowledge of a new board candidate should be evaluated (see Exhibit 1).

Besides, the Netherlands Code included guidelines for supervisory board (SB) including an orientation and education program for new members of SB.

In consideration of corporate governance issues analyzed in the previous sessions, we proposed the main and sub quality factors in this paper a set of general comparative Western European corporate governance standards in a limited model with selected countries. Though limited, it has some implications for further research and proper recommendations to relevant government and organizations. And it also provides relevant academic and non-academic, lawyer and consultant, board and nonboard people with minimum information for further researches.

\section{REFERENCES}

[1] Allen, F., and Gale, D., (1992), Stock Price Manipulation, Review of Financial Studies

[2] Bellouma, Meryem., (2012), Governance Mechanisms and Buyer Supplier Relationship in Tunisian Exporting SMEs, International Journal of Corporate Governance

[3] Campa, Domenico., and Donnelly, Ray., (2013), Board Structure and Monitoring Effects in Different Institutional Settings: A Comparison between Italy and the UK, International Journal of Corporate Governance

[4] Dallas, Lynne., (2011), Short-Termism, The Financial Crisis and Corporate Governance, Journal of Corporation Law 
[5] Essen, Marc., Engelen, Peter., and Carney, Michael., (2013), Does "Good" Corporate Governance Help in A Crisis? The Impact of Country and Firm Level Governance Mechanisms in the European Financial Crisis, Corporate Governance: An International Review

[6] IFRs and US GAPP, Deloitte, 2007.

[7] Khwaja, Asim Ijaz., Mian, Atif., (2005), Unchecked intermediaries:Price manipulation in an emerging stock market, Journal of Financial Economics 78 (2005) 243-241

[8] Niu, Flora., (20008), Director Cash Compensation, Ownership Structure and Director Pay for Performance, International Journal of Corporate Governance

[9] OECD Corporate Governance Guidelines, OECD, 1999

[10] www.iasplus.com

[11] www.cbc.to

[12] www.cii.org/corp_govenance.asp 


\section{Exhibit}

Exhibit 1 - The 2009 Belgian Code of Corporate Governance (a short summary evaluation)

\begin{tabular}{|c|c|c|c|c|c|}
\hline $\begin{array}{l}\text { Subjects or } \\
\text { parties }\end{array}$ & $\begin{array}{c}\begin{array}{c}\text { Main quality } \\
\text { factors }\end{array} \\
\end{array}$ & $\begin{array}{l}\text { Sub quality } \\
\text { factors }\end{array}$ & Responsibilities & Objectives & Note \\
\hline $\begin{array}{l}\text { Audit } \\
\text { committee }\end{array}$ & $\begin{array}{l}\text { Chairman of the } \\
\text { board should not be } \\
\text { chair of AC; at } \\
\text { least } 1 \text { with } \\
\text { accounting and } \\
\text { auditing expertise; }\end{array}$ & $\begin{array}{l}\text { Review IA } \\
\text { function; Set } \\
\text { up by board; }\end{array}$ & $\begin{array}{l}\text { Terms mentioned in CG } \\
\text { charter; New AC members } \\
\text { provided with IC, RM, } \\
\text { operational, financial, } \\
\text { accounting and auditing } \\
\text { information; }\end{array}$ & $\begin{array}{c}\frac{\text { Not }}{\text { mentioned }} \\
\frac{\underline{\text { clearly in the }}}{\underline{\text { code; }}}\end{array}$ & \\
\hline $\begin{array}{l}\text { Nomination } \\
\text { committee }\end{array}$ & $\begin{array}{l}\text { Assist board on } \\
\text { nomination and } \\
\text { planning of CEO; } \\
\text { majority comprises } \\
\text { independent NEDs; }\end{array}$ & $\begin{array}{l}\text { Set up by } \\
\text { board; has } \\
\text { remuneration } \\
\text { report; with } \\
\text { basic, variable } \\
\text { remuneration, } \\
\text { pension; }\end{array}$ & $\begin{array}{l}\text { Terms mentioned in CG } \\
\text { charter; recommend suitable } \\
\text { candidates for board; } \\
\text { recommends appointment } \\
\text { CEO; meet at least twice a } \\
\text { year; }\end{array}$ & $\begin{array}{c}\frac{\text { Not }}{\text { mentioned }} \\
\frac{\underline{\text { clearly in the }}}{\text { code; }}\end{array}$ & \\
\hline $\begin{array}{l}\text { Compensation, } \\
\text { Remuneration } \\
\text { committee }\end{array}$ & $\begin{array}{l}\text { Meet at least } \\
\text { twice a year; }\end{array}$ & $\begin{array}{l}\text { Set up by } \\
\text { board; } \\
\text { remuneration } \\
\text { to attract, } \\
\text { retain, } \\
\text { motivate } \\
\text { directors; }\end{array}$ & $\begin{array}{l}\text { Terms mentioned in CG } \\
\text { charter; make proposals to } \\
\text { board; }\end{array}$ & $\frac{\frac{\text { Not }}{\text { mentioned }}}{\frac{\underline{\text { clearly in the }}}{\underline{\text { code; }}}}$ & \\
\hline $\begin{array}{l}\text { CEO } \\
/ \text { President/MD }\end{array}$ & $\begin{array}{l}\text { Not mentioned } \\
\text { clearly in the code; }\end{array}$ & $\begin{array}{l}\text { Join } \\
\text { meetings of } \\
\text { remuneration } \\
\text { committee; }\end{array}$ & $\begin{array}{l}\text { Clear division of duties b.t } \\
\text { running the board and } \\
\text { running firm business; }\end{array}$ & $\begin{array}{l}\frac{\text { Not }}{\text { mentioned }} \\
\frac{\text { clearly in the }}{\text { code; }}\end{array}$ & \\
\hline The Chair & $\begin{array}{c}\text { Promote } \\
\text { effective } \\
\text { interaction b.t } \\
\text { executive MGT } \\
\text { and board; }\end{array}$ & $\begin{array}{c}\text { Take } \\
\text { necessary } \\
\text { measures to } \\
\text { develop a } \\
\text { climate of } \\
\text { trust; }\end{array}$ & $\begin{array}{c}\text { Should not be the same } \\
\text { CEO; ensure directors } \\
\text { receive accurate, clear and } \\
\text { timely information; ensure all } \\
\text { directors make } \\
\text { knowledgeable contributions } \\
\text { to board discussion; }\end{array}$ & $\begin{array}{l}\frac{\text { Not }}{\text { mentioned }} \\
\frac{\text { clearly in the }}{\text { code; }}\end{array}$ & \\
\hline $\begin{array}{l}\text { CEO and The } \\
\text { Chair } \\
\text { relationship }\end{array}$ & $\begin{array}{l}\text { Chairman fully } \\
\text { respect executive } \\
\text { responsibilities of } \\
\text { CEO; }\end{array}$ & $\begin{array}{l}\text { Chairman } \\
\text { supports, } \\
\text { advises CEO; } \\
\text { division of } \\
\text { duties } \\
\text { clarified; }\end{array}$ & $\begin{array}{l}\text { Chairman establishes close } \\
\text { relationship with CEO; }\end{array}$ & $\begin{array}{c}\frac{\text { Not }}{\text { mentioned }} \\
\frac{\underline{\text { clearly in the }}}{\text { code; }}\end{array}$ & \\
\hline $\begin{array}{l}\text { Corporate } \\
\text { Secretary }\end{array}$ & $\begin{array}{l}\text { Not mentioned } \\
\text { clearly in the code; }\end{array}$ & $\frac{\underline{\text { Not }}}{\frac{\text { mentioned }}{\text { clearly in the }}}$ & $\begin{array}{l}\text { Board describes roles and } \\
\text { tasks of secretary; }\end{array}$ & $\begin{array}{l}\frac{\text { Not }}{\text { mentioned }} \\
\frac{\text { clearly in the }}{\text { code; }}\end{array}$ & \\
\hline $\begin{array}{l}\text { Compliance } \\
\text { officer }\end{array}$ & $\begin{array}{l}\text { Not mentioned } \\
\text { clearly in the code; }\end{array}$ & $\begin{array}{c}\frac{\text { Not }}{\text { mentioned }} \\
\text { clearly in the } \\
\text { code; }\end{array}$ & $\frac{\text { Not mentioned clearly in }}{\text { the code; }}$ & $\begin{array}{c}\frac{\text { Not }}{\text { mentioned }} \\
\text { clearly in the } \\
\underline{\text { code; }}\end{array}$ & \\
\hline $\begin{array}{l}\text { Board of } \\
\text { Directors }\end{array}$ & $\begin{array}{l}\text { Independent (at } \\
\text { least } 3 \text { NEDs) }\end{array}$ & $\begin{array}{l}\text { One tier } \\
\text { board; pay } \\
\text { attention to } \\
\text { CSR, gender } \\
\text { and diversity; }\end{array}$ & $\begin{array}{c}\text { Terms mentioned in } \mathrm{CG} \\
\text { charter; adapts its governance } \\
\text { structure to evolving needs; } \\
\text { ensure financial and HR } \\
\text { resource in place; }\end{array}$ & $\begin{array}{l}\text { Ensure } \\
\text { effective } \\
\text { monitor and } \\
\text { control; }\end{array}$ & \\
\hline $\begin{array}{l}\text { Executive/Rep } \\
\text { resentative } \\
\text { director }\end{array}$ & $\begin{array}{l}\text { Independency of } \\
\text { judgement and } \\
\text { objectivity in } \\
\text { making board }\end{array}$ & In board; & $\begin{array}{l}\text { Provide all business and } \\
\text { financial information to } \\
\text { board; }\end{array}$ & $\begin{array}{c}\frac{\text { Not }}{\text { mentioned }} \\
\frac{\underline{\text { clearly in the }}}{\text { code; }}\end{array}$ & \\
\hline
\end{tabular}


Network Intelligence Studies

Volume I, Issue 2, 2013

\begin{tabular}{|c|c|c|c|c|}
\hline & decisions; & & & \\
\hline $\begin{array}{l}\text { Non-executive } \\
\text { director }\end{array}$ & $\begin{array}{l}\text { Independency of } \\
\text { judgement and } \\
\text { objectivity in } \\
\text { making board } \\
\text { decisions; }\end{array}$ & $\begin{array}{l}\text { In board; } 1 / 2 \\
\text { board } \\
\text { comprises } \\
\text { NED; }\end{array}$ & $\begin{array}{l}\text { Help develop strategies } \\
\text { and key policies proposed by } \\
\text { executive MGT; meet at least } \\
\text { once a year w/o CEO and } \\
\text { other EDs; }\end{array}$ & $\begin{array}{l}\frac{\text { Not }}{\text { mentioned }} \\
\frac{\underline{\text { clearly in the }}}{\text { code; }}\end{array}$ \\
\hline $\begin{array}{l}\text { Independent } \\
\text { director }\end{array}$ & $\begin{array}{l}\text { Independency of } \\
\text { judgement and } \\
\text { objectivity in } \\
\text { making board } \\
\text { decisions; }\end{array}$ & $\begin{array}{l}\text { Not an } \\
\text { executive } \\
\text { member of } \\
\text { board; }\end{array}$ & $\frac{\text { Not mentioned clearly in }}{\underline{\text { the code; }}}$ & $\frac{\frac{\text { Not }}{\text { mentioned }}}{\frac{\text { clearly in the }}{\text { code; }}}$ \\
\hline $\mathrm{CFO}$ & $\begin{array}{l}\text { Not mentioned } \\
\text { clearly in the code; }\end{array}$ & $\frac{\begin{array}{c}\text { Not } \\
\text { mentioned } \\
\text { clearly in the }\end{array}}{\underline{\text { code; }}}$ & $\begin{array}{l}\text { AC decides when CFO, } \\
\text { CEO attend meeting; }\end{array}$ & $\begin{array}{c}\frac{\text { Not }}{\text { mentioned }} \\
\frac{\text { clearly in the }}{\text { code; }}\end{array}$ \\
\hline $\begin{array}{l}\text { Management } \\
\text { team (Senior } \\
\text { Administration } \\
\text { ) }\end{array}$ & $\begin{array}{l}\text { Board decides } \\
\text { structure, powers, } \\
\text { duties of MGT; }\end{array}$ & $\begin{array}{l}\text { Careful } \\
\text { MGT of } \\
\text { potential risks; } \\
\text { executive } \\
\text { MGT include } \\
\text { all EDs; } \\
\end{array}$ & $\begin{array}{l}\text { Board reviews executive } \\
\text { MGT performance; }\end{array}$ & $\begin{array}{l}\frac{\text { Not }}{\text { mentioned }} \\
\frac{\text { clearly in the }}{\underline{\text { code; }}}\end{array}$ \\
\hline $\begin{array}{l}\text { Supervisory } \\
\text { for the board }\end{array}$ & $\begin{array}{l}\text { Not mentioned } \\
\text { clearly in the code; }\end{array}$ & $\begin{array}{c}\text { Proper } \\
\text { supervision of } \\
\text { conformity; }\end{array}$ & $\begin{array}{l}\text { Directors have access to } \\
\text { independent professional } \\
\text { advice; }\end{array}$ & $\begin{array}{l}\frac{\text { Not }}{\text { mentioned }} \\
\frac{\text { clearly in the }}{\text { code; }}\end{array}$ \\
\hline $\begin{array}{l}\text { Supervisory } \\
\text { for the } \\
\text { managers }\end{array}$ & $\begin{array}{l}\text { Not mentioned } \\
\text { clearly in the code; }\end{array}$ & $\begin{array}{c}\frac{\text { Not }}{\text { mentioned }} \\
\frac{\text { clearly in the }}{\text { code; }}\end{array}$ & Acts by board; & $\begin{array}{l}\frac{\text { Not }}{\text { mentioned }} \\
\text { clearly in the } \\
\text { code; }\end{array}$ \\
\hline Internal control & $\begin{array}{l}\text { Not mentioned } \\
\text { clearly in the code; }\end{array}$ & $\begin{array}{c}\text { A } \\
\text { framework of } \\
\text { IC set by } \\
\text { executive } \\
\text { MGT } \\
\text { approved by } \\
\text { board; }\end{array}$ & $\begin{array}{l}\text { Main features written in } \\
\text { CG statement; executive } \\
\text { MGT set IC systems to } \\
\text { assess, identify, manage } \\
\text { risks; }\end{array}$ & $\frac{\underline{\text { Not }}}{\frac{\text { mentioned }}{\text { clearly in the }}} \frac{\text { code; }}{\underline{\text { code }}}$ \\
\hline $\begin{array}{l}\text { Internal or } \\
\text { statutory audit }\end{array}$ & $\begin{array}{l}\text { Not mentioned } \\
\text { clearly in the code; }\end{array}$ & $\begin{array}{l}\text { Guaranteed } \\
\text { free access to } \\
\text { board; }\end{array}$ & $\begin{array}{l}\text { Board supervises IA } \\
\text { function; }\end{array}$ & $\frac{\begin{array}{c}\text { Not } \\
\text { mentioned } \\
\text { clearly in the }\end{array}}{\text { code; }}$ \\
\hline External audit & $\begin{array}{l}\text { Not mentioned } \\
\text { clearly in the code; }\end{array}$ & $\begin{array}{l}\text { Guaranteed } \\
\text { free access to } \\
\text { board; }\end{array}$ & $\begin{array}{l}\text { Comment on the true and } \\
\text { fair view of the firm assets } \\
\text { and liabilities, financial } \\
\text { positions; report AC key } \\
\text { matters of FS; }\end{array}$ & $\begin{array}{c}\text { In } \\
\text { accordance with } \\
\text { financial } \\
\text { reporting } \\
\text { framework in } \\
\text { Belgium; }\end{array}$ \\
\hline $\begin{array}{l}\text { Disclosure and } \\
\text { transparency }\end{array}$ & $\begin{array}{l}\text { Executive MGT } \\
\text { prepare firm } \\
\text { disclosure of F.S; }\end{array}$ & $\begin{array}{l}\text { Through CG } \\
\text { charter and CG } \\
\text { statement; }\end{array}$ & $\begin{array}{l}\text { Allow effective external } \\
\text { monitoring; }\end{array}$ & $\begin{array}{l}\text { A high level } \\
\text { of transparency; } \\
\text { promote } \\
\text { effective } \\
\text { dialogue with } \\
\text { (potential) } \\
\text { shareholders; }\end{array}$ \\
\hline $\begin{array}{l}\text { Shareholders } \\
\text { and Minority } \\
\text { Stockholder }\end{array}$ & $\begin{array}{c}\text { A website } \\
\text { section describes } \\
\text { their rights to join } \\
\text { GM; }\end{array}$ & $\begin{array}{l}\text { Respect } \\
\text { rights of } \\
\text { minority } \\
\text { shareholders; }\end{array}$ & $\begin{array}{l}\text { Controlling shareholders } \\
\text { can appoint representatives to } \\
\text { the board; Board ensures its } \\
\text { obligations to shareholders } \\
\text { are met; }\end{array}$ & $\frac{\begin{array}{c}\text { Not } \\
\text { mentioned } \\
\text { clearly in the }\end{array}}{\underline{\text { code; }}}$ \\
\hline Accountability & $\begin{array}{r}\text { Not mentioned } \\
\text { clearly in the code; }\end{array}$ & $\begin{array}{l}\text { Demands on } \\
\text { business }\end{array}$ & $\begin{array}{c}\text { Executive MGT } \\
\text { accountable to board for the }\end{array}$ & $\begin{array}{c}\underline{\text { Not }} \\
\underline{\text { mentioned }}\end{array}$ \\
\hline
\end{tabular}


Network Intelligence Studies

Volume I, Issue 2, 2013

\begin{tabular}{|c|c|c|c|c|c|}
\hline & & leaders; & discharge of its duties; & $\frac{\text { clearly in the }}{\text { code; }}$ & \\
\hline Leadership & $\begin{array}{l}\text { Not mentioned } \\
\text { clearly in the code; }\end{array}$ & $\begin{array}{l}\text { Chairman } \\
\text { responsible for } \\
\text { leadership of } \\
\text { board; }\end{array}$ & $\begin{array}{c}\text { Board provides } \\
\text { entrepreneur leadership; }\end{array}$ & $\begin{array}{l}\frac{\text { Not }}{\text { mentioned }} \\
\text { clearly in the } \\
\text { code; }\end{array}$ & \\
\hline Employee & $\begin{array}{l}\text { Not mentioned } \\
\text { clearly in the code; }\end{array}$ & $\begin{array}{l}\text { AC decides } \\
\text { whether senior } \\
\text { employee join } \\
\text { meeting; }\end{array}$ & $\begin{array}{l}\text { At GM, directors answer } \\
\text { questions which do not } \\
\text { prejudice firm, employee, } \\
\text { shareholders; }\end{array}$ & $\begin{array}{l}\frac{\text { Not }}{\text { mentioned }} \\
\frac{\text { clearly in the }}{\text { code; }}\end{array}$ & \\
\hline $\begin{array}{l}3^{\text {rd }} \text { parties and } \\
\text { conflicts of } \\
\text { interests }\end{array}$ & $\begin{array}{l}\text { Not mentioned } \\
\text { clearly in the code; }\end{array}$ & $\begin{array}{l}\text { Have a } \\
\text { policy; }\end{array}$ & $\begin{array}{l}\text { Each board member avoid } \\
\text { direct and indirect conflicts } \\
\text { of interest; }\end{array}$ & $\begin{array}{l}\frac{\text { Not }}{\text { mentioned }} \\
\text { clearly in the } \\
\text { code; }\end{array}$ & \\
\hline $\begin{array}{l}\text { Code of ethics } \\
\text { (conduct) }\end{array}$ & $\begin{array}{l}\text { Not mentioned } \\
\text { clearly in the code; }\end{array}$ & $\begin{array}{l}\frac{\text { Not }}{\text { mentioned }} \\
\frac{\text { clearly in the }}{\text { code; }}\end{array}$ & $\frac{\text { Not mentioned clearly in }}{\text { the code; }}$ & $\begin{array}{l}\frac{\text { Not }}{\text { mentioned }} \\
\frac{\text { clearly in the }}{\text { code; }}\end{array}$ & \\
\hline $\begin{array}{l}\text { Group and } \\
\text { subsidiaries }\end{array}$ & $\begin{array}{l}\text { Not mentioned } \\
\text { clearly in the code; }\end{array}$ & $\begin{array}{c}\frac{\text { Not }}{\text { mentioned }} \\
\text { clearly in the } \\
\text { code; }\end{array}$ & $\begin{array}{l}\text { A policy for transactions } \\
\text { with related firms included in } \\
\text { CG charter; }\end{array}$ & $\begin{array}{l}\frac{\text { Not }}{\text { mentioned }} \\
\frac{\text { clearly in the }}{\text { code; }}\end{array}$ & \\
\hline CG Code itself & $\begin{array}{c}\text { Set a proper } \\
\text { balance b.t } \\
\text { leadership, } \\
\text { entrepreneurship } \\
\text { and performance; } \\
\text { as well as control } \\
\text { and conformity; }\end{array}$ & $\begin{array}{c}\text { Ensure } \\
\text { leadership, } \\
\text { integrity and } \\
\text { transparency } \\
\text { in the decision } \\
\text { making } \\
\text { process; }\end{array}$ & $\begin{array}{l}\text { Help determines firm } \\
\text { goals; one-tier board model; } \\
\text { has principles, provisions and } \\
\text { guidelines; }\end{array}$ & $\begin{array}{l}\text { Create more } \\
\text { and faster } \\
\text { transparency; } \\
\text { long term value } \\
\text { creation; }\end{array}$ & \\
\hline $\begin{array}{l}\text { Management } \\
\text { system }\end{array}$ & $\begin{array}{l}\text { Not mentioned } \\
\text { clearly in the code; }\end{array}$ & $\begin{array}{l}\frac{\text { Not }}{\text { mentioned }} \\
\frac{\text { clearly in the }}{\text { code; }}\end{array}$ & $\begin{array}{l}\text { Main features of risk MGT } \\
\text { system mentioned in CG } \\
\text { statement; }\end{array}$ & $\frac{\begin{array}{l}\text { Not } \\
\text { mentioned } \\
\text { clearly in the }\end{array}}{\underline{\text { code; }}}$ & \\
\hline Note & \multicolumn{5}{|c|}{$\begin{array}{c}\text { The underlined part is describing some more works needed to be done for relevant subjects and } \\
\text { parties. }\end{array}$} \\
\hline
\end{tabular}

Exhibit 2 - The Netherlands Code of Governance (a short summary evaluation)

\begin{tabular}{|c|c|c|c|c|c|}
\hline $\begin{array}{l}\text { Subjects or } \\
\text { parties }\end{array}$ & $\begin{array}{l}\text { Main quality } \\
\text { factors }\end{array}$ & $\begin{array}{l}\text { Sub quality } \\
\text { factors }\end{array}$ & Responsibilities & Objectives & Note \\
\hline $\begin{array}{l}\text { Audit } \\
\text { committee }\end{array}$ & $\begin{array}{l}\text { Maintain } \\
\text { professional } \\
\text { relationship with } \\
\text { IA and EA; }\end{array}$ & $\begin{array}{l}\text { Direct } \\
\text { communicatio } \\
\text { n channels to } \\
\text { IA and EA; }\end{array}$ & SB establish AC; & $\frac{\frac{\text { Not }}{\text { mentioned }}}{\frac{\text { clearly in the }}{\text { code; }}}$ & \\
\hline $\begin{array}{l}\text { Nomination } \\
\text { committee }\end{array}$ & $\begin{array}{l}\text { Not mentioned } \\
\text { clearly in the code; }\end{array}$ & $\begin{array}{l}\text { S.D selected } \\
\text { through a } \\
\text { formal } \\
\text { process; }\end{array}$ & $\begin{array}{c}\text { Has a nomination } \\
\text { committee of supervisory } \\
\text { directors (S.D); }\end{array}$ & $\begin{array}{c}\frac{\text { Not }}{\text { mentioned }} \\
\frac{\text { clearly in the }}{\text { code; }}\end{array}$ & \\
\hline $\begin{array}{l}\text { Compensati } \\
\text { on, } \\
\text { Remuneration } \\
\text { committee }\end{array}$ & $\begin{array}{l}\text { Not mentioned } \\
\text { clearly in the code; }\end{array}$ & $\begin{array}{c}\frac{\text { Not }}{\text { mentioned }} \\
\frac{\text { clearly in the }}{\text { code; }}\end{array}$ & $\frac{\text { Not mentioned clearly in }}{\text { the code; }}$ & $\frac{\underline{\text { Not }}}{\text { mentioned }} \frac{\text { clearly in the }}{\text { code; }}$ & \\
\hline $\begin{array}{l}\text { CEO } \\
\text { /President/MD }\end{array}$ & $\begin{array}{l}\text { Not mentioned } \\
\text { clearly in the code; }\end{array}$ & $\begin{array}{l}\frac{\text { Not }}{\text { mentioned }} \\
\text { clearly in the } \\
\text { code; }\end{array}$ & $\frac{\text { Not mentioned clearly in }}{\text { the code; }}$ & $\begin{array}{l}\frac{\text { Not }}{\text { mentioned }} \\
\text { clearly in the } \\
\underline{\text { code; }}\end{array}$ & \\
\hline The Chair & Not mentioned & Not & Not mentioned clearly in & Not & \\
\hline
\end{tabular}


Network Intelligence Studies

Volume I, Issue 2, 2013

\begin{tabular}{|c|c|c|c|c|}
\hline & clearly in the code; & $\frac{\frac{\text { mentioned }}{\text { clearly in the }}}{\text { code; }}$ & the code; & $\frac{\frac{\text { mentioned }}{\text { clearly in the }}}{\text { code; }}$ \\
\hline $\begin{array}{l}\text { CEO and } \\
\text { The Chair } \\
\text { relationship }\end{array}$ & $\begin{array}{l}\text { Not mentioned } \\
\text { clearly in the code; }\end{array}$ & $\begin{array}{c}\frac{\text { Not }}{\text { mentioned }} \\
\frac{\text { clearly in the }}{\text { code; }}\end{array}$ & $\frac{\text { Not mentioned clearly in }}{\text { the code; }}$ & $\begin{array}{c}\frac{\text { Not }}{\text { mentioned }} \\
\frac{\text { clearly in the }}{\text { code; }}\end{array}$ \\
\hline $\begin{array}{l}\text { Corporate } \\
\text { Secretary }\end{array}$ & $\begin{array}{l}\text { Not mentioned } \\
\text { clearly in the code; }\end{array}$ & $\frac{\frac{\text { Not }}{\text { mentioned }}}{\frac{\text { clearly in the }}{\text { code; }}}$ & $\frac{\text { Not mentioned clearly in }}{\text { the code; }}$ & $\frac{\frac{\text { Not }}{\text { mentioned }}}{\frac{\text { clearly in the }}{\text { code; }}}$ \\
\hline $\begin{array}{l}\text { Compliance } \\
\text { officer }\end{array}$ & $\begin{array}{l}\text { Not mentioned } \\
\text { clearly in the code; }\end{array}$ & $\begin{array}{c}\frac{\text { Not }}{\text { mentioned }} \\
\text { clearly in the } \\
\text { code; }\end{array}$ & $\begin{array}{l}\text { A compliance committee } \\
\text { installed, or a high level } \\
\text { compliance officer } \\
\text { appointed; }\end{array}$ & $\begin{array}{c}\frac{\text { Not }}{\text { mentioned }} \\
\frac{\text { clearly in the }}{\text { code; }}\end{array}$ \\
\hline $\begin{array}{l}\text { Board of } \\
\text { Directors }\end{array}$ & $\begin{array}{l}\text { Not mentioned } \\
\text { clearly in the code; }\end{array}$ & $\begin{array}{l}\frac{\text { Not }}{\text { mentioned }} \\
\frac{\text { clearly in the }}{\text { code; }}\end{array}$ & $\begin{array}{l}\text { Adopt strategy; training } \\
\text { senior MGT; }\end{array}$ & $\begin{array}{l}\frac{\text { Not }}{\text { mentioned }} \\
\frac{\text { clearly in the }}{\text { code; }}\end{array}$ \\
\hline $\begin{array}{l}\text { Executive/R } \\
\text { epresentative } \\
\text { director }\end{array}$ & $\begin{array}{l}\text { Not mentioned } \\
\text { clearly in the code; }\end{array}$ & $\begin{array}{c}\frac{\text { Not }}{\text { mentioned }} \\
\frac{\text { clearly in the }}{\text { code; }}\end{array}$ & $\begin{array}{l}\text { SB reviews compensation } \\
\text { of ED, reflecting duties and } \\
\text { risks; }\end{array}$ & $\begin{array}{c}\frac{\text { Not }}{\text { mentioned }} \\
\frac{\text { clearly in the }}{\text { code; }}\end{array}$ \\
\hline $\begin{array}{l}\text { Non- } \\
\text { executive } \\
\text { director }\end{array}$ & $\begin{array}{l}\text { Not mentioned } \\
\text { clearly in the code; }\end{array}$ & $\begin{array}{l}\frac{\text { Not }}{\text { mentioned }} \\
\frac{\text { clearly in the }}{\text { code; }}\end{array}$ & $\frac{\text { Not mentioned clearly in }}{\text { the code; }}$ & $\begin{array}{l}\frac{\text { Not }}{\text { mentioned }} \\
\frac{\text { clearly in the }}{\text { code; }}\end{array}$ \\
\hline $\begin{array}{l}\text { Independent } \\
\text { director }\end{array}$ & $\begin{array}{l}\text { Not mentioned } \\
\text { clearly in the code; }\end{array}$ & $\begin{array}{l}\frac{\text { Not }}{\text { mentioned }} \\
\frac{\text { clearly in the }}{\text { code; }}\end{array}$ & $\frac{\text { Not mentioned clearly in }}{\text { the code; }}$ & $\begin{array}{l}\frac{\text { Not }}{\text { mentioned }} \\
\frac{\text { clearly in the }}{\text { code; }}\end{array}$ \\
\hline $\mathrm{CFO}$ & $\begin{array}{l}\text { Not mentioned } \\
\text { clearly in the code; }\end{array}$ & $\begin{array}{c}\frac{\text { Not }}{\text { mentioned }} \\
\frac{\text { clearly in the }}{\text { code; }}\end{array}$ & $\frac{\text { Not mentioned clearly in }}{\text { the code; }}$ & $\begin{array}{c}\frac{\text { Not }}{\text { mentioned }} \\
\frac{\text { clearly in the }}{\text { code; }}\end{array}$ \\
\hline $\begin{array}{l}\text { Managemen } \\
\text { t team (Senior } \\
\text { Administration } \\
\text { ) }\end{array}$ & $\begin{array}{c}\text { Meeting for } \\
\text { objectives } \\
\text { developed by SB; }\end{array}$ & $\begin{array}{l}\text { Invited once } \\
\text { a year to } \\
\text { discuss mgt } \\
\text { report; }\end{array}$ & $\begin{array}{c}\text { Supervisory board } \\
\text { develops position } \\
\text { descriptions for senior mgt } \\
\text { and limits to mgt duties; }\end{array}$ & $\begin{array}{l}\text { SB ensure } \\
\text { competent } \\
\text { MGT on an } \\
\text { ongoing basis; }\end{array}$ \\
\hline $\begin{array}{l}\text { Supervisory } \\
\text { for the board }\end{array}$ & $\begin{array}{l}\text { Approve/develo } \\
\text { p corporate } \\
\text { objectives; }\end{array}$ & $\begin{array}{c}\text { Function } \\
\text { independently } \\
\text { of mgt; } \\
\text { appropriate } \\
\text { structure and } \\
\text { procedures; }\end{array}$ & $\begin{array}{l}\text { Set adequate information, } \\
\text { documentation and reporting } \\
\text { system; }\end{array}$ & $\begin{array}{l}\text { Monitor the } \\
\text { operations and } \\
\text { firm } \\
\text { performance; }\end{array}$ \\
\hline $\begin{array}{l}\text { Supervisory } \\
\text { for the } \\
\text { managers }\end{array}$ & $\begin{array}{l}\text { Not mentioned } \\
\text { clearly in the code; }\end{array}$ & $\begin{array}{l}\frac{\text { Not }}{\text { mentioned }} \\
\frac{\text { clearly in the }}{\text { code; }}\end{array}$ & $\begin{array}{l}\text { SB ensures individuals } \\
\text { involved in daily MGT are of } \\
\text { professional, integrity and } \\
\text { social and moral; }\end{array}$ & $\begin{array}{l}\frac{\text { Not }}{\text { mentioned }} \\
\frac{\text { clearly in the }}{\text { code; }}\end{array}$ \\
\hline $\begin{array}{l}\text { Internal } \\
\text { control }\end{array}$ & $\begin{array}{l}\text { Not mentioned } \\
\text { clearly in the code; }\end{array}$ & $\begin{array}{l}\frac{\text { Not }}{\text { mentioned }} \\
\text { clearly in the } \\
\text { code; }\end{array}$ & $\begin{array}{l}\text { Supervisory board } \\
\text { responsible for the integrity } \\
\text { of IC and MIS; }\end{array}$ & $\begin{array}{l}\frac{\text { Not }}{\text { mentioned }} \\
\frac{\text { clearly in the }}{\text { code; }}\end{array}$ \\
\hline $\begin{array}{c}\text { Internal or } \\
\text { statutory audit }\end{array}$ & $\begin{array}{l}\text { Not mentioned } \\
\text { clearly in the code; }\end{array}$ & $\begin{array}{c}\frac{\text { Not }}{\text { mentioned }} \\
\frac{\text { clearly in the }}{\text { code; }}\end{array}$ & $\frac{\text { Not mentioned clearly in }}{\text { the code; }}$ & 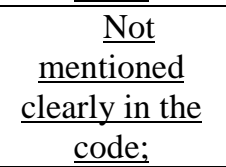 \\
\hline $\begin{array}{l}\text { External } \\
\text { audit }\end{array}$ & $\begin{array}{l}\text { Not mentioned } \\
\text { clearly in the code; }\end{array}$ & $\begin{array}{c}\underline{\text { Not }} \\
\text { mentioned } \\
\text { clearly in the }\end{array}$ & $\frac{\text { Not mentioned clearly in }}{\text { the code; }}$ & $\begin{array}{c}\underline{\text { Not }} \\
\text { mentioned } \\
\text { clearly in the }\end{array}$ \\
\hline
\end{tabular}


Network Intelligence Studies

Volume I, Issue 2, 2013

\begin{tabular}{|c|c|c|c|c|c|}
\hline & & code; & & code; & \\
\hline $\begin{array}{l}\text { Disclosure } \\
\text { and } \\
\text { transparency }\end{array}$ & $\begin{array}{l}\text { Not mentioned } \\
\text { clearly in the code; }\end{array}$ & $\begin{array}{c}\frac{\text { Not }}{\text { mentioned }} \\
\frac{\text { clearly in the }}{\text { code; }}\end{array}$ & $\frac{\text { Not mentioned clearly in }}{\text { the code; }}$ & $\begin{array}{c}\frac{\text { Not }}{\text { mentioned }} \\
\frac{\text { clearly in the }}{\text { code; }}\end{array}$ & \\
\hline $\begin{array}{l}\text { Shareholder } \\
\text { s and Minority } \\
\text { Stockholder }\end{array}$ & $\begin{array}{l}\text { Not mentioned } \\
\text { clearly in the code; }\end{array}$ & 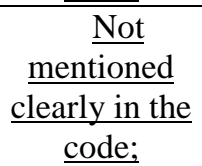 & $\frac{\text { Not mentioned clearly in }}{\text { the code; }}$ & $\frac{\begin{array}{c}\text { Not } \\
\text { mentioned } \\
\text { clearly in the }\end{array}}{\text { code; }}$ & \\
\hline $\begin{array}{l}\text { Accountabili } \\
\text { ty }\end{array}$ & $\begin{array}{l}\text { Not mentioned } \\
\text { clearly in the code; }\end{array}$ & $\begin{array}{c}\frac{\text { Not }}{\text { mentioned }} \\
\frac{\text { clearly in the }}{\text { code; }}\end{array}$ & $\frac{\text { Not mentioned clearly in }}{\text { the code; }}$ & $\begin{array}{c}\frac{\text { Not }}{\text { mentioned }} \\
\frac{\text { clearly in the }}{\text { code; }}\end{array}$ & \\
\hline Leadership & $\begin{array}{l}\text { Not mentioned } \\
\text { clearly in the code; }\end{array}$ & $\frac{\begin{array}{c}\text { Not } \\
\text { mentioned } \\
\text { clearly in the }\end{array}}{\text { code; }}$ & $\frac{\text { Not mentioned clearly in }}{\text { the code; }}$ & $\begin{array}{l}\frac{\text { Not }}{\text { mentioned }} \\
\frac{\text { clearly in the }}{\text { code; }}\end{array}$ & \\
\hline Employee & $\begin{array}{l}\text { Not mentioned } \\
\text { clearly in the code; }\end{array}$ & $\begin{array}{c}\frac{\text { Not }}{\text { mentioned }} \\
\frac{\text { clearly in the }}{\text { code; }}\end{array}$ & $\frac{\text { Not mentioned clearly in }}{\text { the code; }}$ & $\begin{array}{c}\frac{\text { Not }}{\text { mentioned }} \\
\frac{\text { clearly in the }}{\text { code; }}\end{array}$ & \\
\hline $\begin{array}{l}\quad 3^{\text {rd }} \text { parties } \\
\text { and conflicts } \\
\text { of interests }\end{array}$ & $\begin{array}{l}\text { Not mentioned } \\
\text { clearly in the code; }\end{array}$ & $\frac{\frac{\text { Not }}{\text { mentioned }}}{\text { clearly in the }}$ & $\begin{array}{l}\text { Unrelated supervisory } \\
\text { director free from any of } \\
\text { interest; }\end{array}$ & 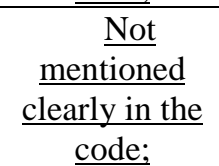 & \\
\hline $\begin{array}{l}\text { Code of } \\
\text { ethics } \\
\text { (conduct) }\end{array}$ & $\begin{array}{r}\text { Not mentioned } \\
\text { clearly in the code; }\end{array}$ & $\begin{array}{c}\frac{\text { Not }}{\text { mentioned }} \\
\frac{\text { clearly in the }}{\text { code; }}\end{array}$ & $\frac{\text { Not mentioned clearly in }}{\text { the code; }}$ & 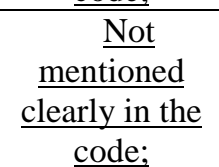 & \\
\hline $\begin{array}{l}\text { Group and } \\
\text { subsidiaries }\end{array}$ & $\begin{array}{r}\text { Not mentioned } \\
\text { clearly in the code; }\end{array}$ & $\begin{array}{c}\frac{\text { Not }}{\text { mentioned }} \\
\frac{\text { clearly in the }}{\text { code; }}\end{array}$ & $\begin{array}{c}\text { Not mentioned clearly in } \\
\text { the code; }\end{array}$ & $\begin{array}{c}\frac{\text { Not }}{\text { mentioned }} \\
\frac{\text { clearly in the }}{\text { code; }}\end{array}$ & \\
\hline $\begin{array}{l}\text { CG Code } \\
\text { itself }\end{array}$ & $\begin{array}{r}\text { Not mentioned } \\
\text { clearly in the code; }\end{array}$ & $\frac{\underline{\text { Not }}}{\frac{\text { mentioned }}{\text { clearly in the }}} \frac{\text { code; }}{\text { code }}$ & $\begin{array}{l}\text { SB assign committee of } \\
\text { S.D duties for developing } \\
\text { firm approach to CG; }\end{array}$ & 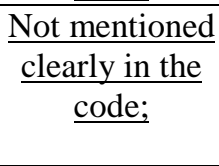 & \\
\hline $\begin{array}{l}\text { Managemen } \\
\text { t system }\end{array}$ & $\begin{array}{l}\text { Not mentioned } \\
\text { clearly in the code; }\end{array}$ & $\begin{array}{c}\frac{\text { Not }}{\text { mentioned }} \\
\frac{\text { clearly in the }}{\text { code; }}\end{array}$ & $\frac{\text { Not mentioned clearly in }}{\text { the code; }}$ & $\frac{\underline{\text { Not }}}{\underline{\text { mentioned }}} \frac{\text { clearly in the }}{\text { code; }}$ & \\
\hline Note & \multicolumn{5}{|c|}{$\begin{array}{c}\text { The underlined part is describing some more works needed to be done for relevant subjects and } \\
\text { parties. }\end{array}$} \\
\hline
\end{tabular}

Exhibit 3 - Evaluation of Italian 2002 CG Principles

\begin{tabular}{|c|c|c|c|c|c|}
\hline $\begin{array}{l}\text { Subjects or } \\
\text { parties }\end{array}$ & $\begin{array}{l}\text { Main quality } \\
\text { factors }\end{array}$ & $\begin{array}{r}\text { Sub } \\
\text { quality } \\
\text { factors } \\
\end{array}$ & Responsibilities & Objectives & Note \\
\hline $\begin{array}{c}\text { Audit } \\
\text { committee }\end{array}$ & $\begin{array}{l}\text { Not mentioned } \\
\text { clearly in the code; }\end{array}$ & $\begin{array}{l}\text { Set the } \\
\text { board of } \\
\text { auditors, } \\
\text { instead of } \\
\text { AC; }\end{array}$ & $\frac{\text { Not mentioned clearly in }}{\text { the code; }}$ & $\begin{array}{l}\frac{\text { Not }}{\text { mentioned }} \\
\frac{\text { clearly in the }}{\text { code; }}\end{array}$ & \\
\hline $\begin{array}{l}\text { Nomination } \\
\text { committee }\end{array}$ & $\begin{array}{l}\text { Not mentioned } \\
\text { clearly in the code; }\end{array}$ & $\begin{array}{l}\frac{\text { Not }}{\text { mentioned }} \\
\frac{\text { clearly in the }}{\text { code; }}\end{array}$ & $\begin{array}{l}\text { Board set a committee } \\
\text { with NED to appoint } \\
\text { directors/chairman/MD; }\end{array}$ & $\begin{array}{l}\frac{\text { Not }}{\text { mentioned }} \\
\frac{\text { clearly in the }}{\text { code; }}\end{array}$ & \\
\hline Compensati & Consist of NEDs; & Board form & Remuneration of MD; criteria & Not & \\
\hline
\end{tabular}




\begin{tabular}{|c|c|c|c|c|c|}
\hline $\begin{array}{l}\text { on, } \\
\text { Remuneration } \\
\text { committee }\end{array}$ & & it; & for remuneration of top mgt; & $\frac{\frac{\text { mentioned }}{\text { clearly in the }}}{\text { code; }}$ & \\
\hline $\begin{array}{c}\text { CEO } \\
/ \text { President/MD }\end{array}$ & $\begin{array}{l}\text { Not mentioned } \\
\text { clearly in the code; }\end{array}$ & $\begin{array}{l}\text { MD } \\
\text { included in } \\
\text { board; }\end{array}$ & $\begin{array}{l}\text { Keep the board informed } \\
\text { of the main regulatory } \\
\text { innovations in which the firm } \\
\text { operates; identify main risks; }\end{array}$ & $\begin{array}{l}\frac{\text { Not }}{\text { mentioned }} \\
\frac{\text { clearly in the }}{\text { code; }}\end{array}$ & \\
\hline The Chair & $\begin{array}{l}\text { Arranging for } \\
\text { distribution of } \\
\text { information timely } \\
\text { to BD; }\end{array}$ & $\begin{array}{l}\text { Included in } \\
\text { Board; board } \\
\text { delegates } \\
\text { powers to } \\
\text { chairman; }\end{array}$ & $\begin{array}{l}\text { call the board meeting, set } \\
\text { agenda; coordinate activities } \\
\text { of BD; ensure all directors } \\
\text { make a knowledgeable } \\
\text { contribution to board } \\
\text { discussion; }\end{array}$ & $\begin{array}{l}\text { Promote } \\
\text { effective mgt of } \\
\text { firm; }\end{array}$ & \\
\hline $\begin{array}{l}\text { CEO and } \\
\text { The Chair } \\
\text { relationship }\end{array}$ & $\begin{array}{l}\text { Not mentioned } \\
\text { clearly in the code; }\end{array}$ & $\begin{array}{l}\frac{\text { Not }}{\text { mentioned }} \\
\frac{\text { clearly in the }}{\text { code; }}\end{array}$ & BD has a chairman; & $\begin{array}{l}\frac{\text { Not }}{\text { mentioned }} \\
\frac{\text { clearly in the }}{\text { code; }}\end{array}$ & \\
\hline $\begin{array}{l}\text { Corporate } \\
\text { Secretary }\end{array}$ & $\begin{array}{l}\text { Not mentioned } \\
\text { clearly in the code; }\end{array}$ & $\frac{\frac{\text { Not }}{\text { mentioned }}}{\frac{\text { clearly in the }}{\text { code; }}}$ & $\frac{\text { Not mentioned clearly in }}{\text { the code; }}$ & $\frac{\underline{\text { Not }}}{\frac{\text { mentioned }}{\text { clearly in the }}} \frac{\text { code; }}{\text { code }}$ & \\
\hline $\begin{array}{l}\text { Compliance } \\
\text { officer }\end{array}$ & $\begin{array}{l}\text { Not mentioned } \\
\text { clearly in the code; }\end{array}$ & $\begin{array}{l}\frac{\text { Not }}{\text { mentioned }} \\
\frac{\text { clearly in the }}{\text { code; }}\end{array}$ & $\frac{\text { Not mentioned clearly in }}{\text { the code; }}$ & $\begin{array}{l}\frac{\text { Not }}{\text { mentioned }} \\
\text { clearly in the } \\
\text { code; }\end{array}$ & \\
\hline $\begin{array}{l}\text { Board of } \\
\text { Directors }\end{array}$ & $\begin{array}{l}\text { Independence of } \\
\text { judgement; }\end{array}$ & $\begin{array}{l}\text { Meet at } \\
\text { regular } \\
\text { interval; }\end{array}$ & $\begin{array}{l}\text { Set the firm strategic, } \\
\text { financial objectives; } \\
\text { delegates power to MD; } \\
\text { appoint some MD; }\end{array}$ & $\begin{array}{l}\text { Guarantee } \\
\text { effective and } \\
\text { efficient } \\
\text { performance of } \\
\text { its functions; }\end{array}$ & $\begin{array}{l}\text { As } \\
\text { underst } \\
\text { ood } \\
\text { from the } \\
\text { Code; }\end{array}$ \\
\hline $\begin{array}{l}\text { Executive/R } \\
\text { epresentative } \\
\text { director }\end{array}$ & 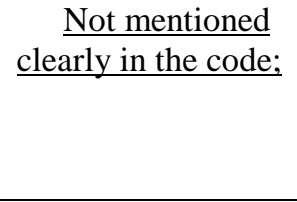 & $\begin{array}{l}\text { ED included } \\
\text { in board; } \\
\text { NED } \\
\text { outnumber } \\
\text { ED; }\end{array}$ & $\frac{\text { Not mentioned clearly in }}{\text { the code; }}$ & $\frac{\frac{\text { Not }}{\text { mentioned }}}{\frac{\text { clearly in the }}{\text { code; }}}$ & \\
\hline $\begin{array}{l}\text { Non- } \\
\text { executive } \\
\text { director }\end{array}$ & $\begin{array}{l}\text { Specific expertise } \\
\text { to board discussion; } \\
\text { the number relates } \\
\text { to size, complexity } \\
\text { and nature of } \\
\text { activity; }\end{array}$ & $\begin{array}{c}\text { Views } \\
\text { carry } \\
\text { significant } \\
\text { weight in } \\
\text { taking board } \\
\text { decision; } \\
\text { independent; } \\
\text { Member of } \\
\text { executive } \\
\text { committee; }\end{array}$ & $\begin{array}{l}\text { Included in board; NED } \\
\text { contribution in matters where } \\
\text { interests of ED and } \\
\text { shareholders not coincide; } \\
\text { bring independent and biased } \\
\text { judgement to resolutions } \\
\text { proposed by MD; }\end{array}$ & $\begin{array}{l}\frac{\text { Not }}{\text { mentioned }} \\
\frac{\text { clearly in the }}{\text { code; }}\end{array}$ & \\
\hline $\begin{array}{l}\text { Independent } \\
\text { director }\end{array}$ & $\begin{array}{l}\text { Not mentioned } \\
\text { clearly in the code; }\end{array}$ & $\begin{array}{l}\text { Member of } \\
\text { executive } \\
\text { committee; }\end{array}$ & $\begin{array}{l}\text { Involved in board } \\
\text { discussion, join in } \\
\text { committee; }\end{array}$ & $\begin{array}{c}\frac{\text { Not }}{\text { mentioned }} \\
\frac{\text { clearly in the }}{\text { code; }}\end{array}$ & \\
\hline $\mathrm{CFO}$ & $\begin{array}{l}\text { Not mentioned } \\
\text { clearly in the code; }\end{array}$ & $\begin{array}{l}\frac{\text { Not }}{\text { mentioned }} \\
\frac{\text { clearly in the }}{\text { code; }}\end{array}$ & $\frac{\text { Not mentioned clearly in }}{\text { the code; }}$ & $\begin{array}{c}\frac{\text { Not }}{\text { mentioned }} \\
\text { clearly in the } \\
\text { code; }\end{array}$ & \\
\hline $\begin{array}{l}\text { Managemen } \\
\mathrm{t} \text { team (Senior } \\
\text { Administration } \\
\text { ) }\end{array}$ & $\begin{array}{l}\text { Not mentioned } \\
\text { clearly in the code; }\end{array}$ & $\begin{array}{l}\frac{\text { Not }}{\text { mentioned }} \\
\frac{\text { clearly in the }}{\text { code; }}\end{array}$ & $\begin{array}{l}\text { Some Directors perform } \\
\text { MGT functions; }\end{array}$ & $\begin{array}{c}\text { Create } \\
\text { maximum value } \\
\text { for } \\
\text { shareholders; }\end{array}$ & \\
\hline $\begin{array}{l}\text { Supervisory } \\
\text { for the board }\end{array}$ & $\begin{array}{l}\text { Not mentioned } \\
\text { clearly in the code; }\end{array}$ & $\begin{array}{c}\frac{\text { Not }}{\text { mentioned }} \\
\text { clearly in the }\end{array}$ & $\frac{\text { Not mentioned clearly in }}{\text { the code; }}$ & $\begin{array}{c}\frac{\text { Not }}{\text { mentioned }} \\
\text { clearly in the }\end{array}$ & \\
\hline
\end{tabular}


Network Intelligence Studies

Volume I, Issue 2, 2013

\begin{tabular}{|c|c|c|c|c|c|}
\hline & & code; & & code; & \\
\hline $\begin{array}{l}\text { Supervisory } \\
\text { for the } \\
\text { managers }\end{array}$ & $\begin{array}{l}\text { Not mentioned } \\
\text { clearly in the code; }\end{array}$ & $\begin{array}{c}\frac{\text { Not }}{\text { mentioned }} \\
\text { clearly in the } \\
\text { code; }\end{array}$ & $\begin{array}{l}\text { Board supervise general } \\
\text { performance of the firm; }\end{array}$ & $\begin{array}{l}\frac{\text { Not }}{\text { mentioned }} \\
\frac{\text { clearly in the }}{\text { code; }}\end{array}$ & $\begin{array}{c}\text { As } \\
\text { underst } \\
\text { ood } \\
\text { from the } \\
\text { code; }\end{array}$ \\
\hline $\begin{array}{l}\text { Internal } \\
\text { control }\end{array}$ & $\begin{array}{l}\text { Processes to } \\
\text { monitor the } \\
\text { efficiency of firm } \\
\text { operation; }\end{array}$ & $\begin{array}{l}\text { Made up } \\
\text { exclusively of } \\
\text { independent } \\
\text { directors; }\end{array}$ & $\begin{array}{c}\text { Set an internal control } \\
\text { committee; BD responsible } \\
\text { for IC; }\end{array}$ & $\begin{array}{c}\frac{\text { Not }}{\text { mentioned }} \\
\frac{\text { clearly in the }}{\text { code; }}\end{array}$ & \\
\hline $\begin{array}{c}\text { Internal or } \\
\text { statutory audit }\end{array}$ & $\begin{array}{l}\text { Not mentioned } \\
\text { clearly in the code; }\end{array}$ & $\begin{array}{l}\frac{\text { Not }}{\text { mentioned }} \\
\frac{\text { clearly in the }}{\text { code; }}\end{array}$ & $\begin{array}{l}\text { The person run IC also the } \\
\text { head of IA; }\end{array}$ & $\begin{array}{c}\frac{\text { Not }}{\text { mentioned }} \\
\frac{\text { clearly in the }}{\text { code; }}\end{array}$ & $\begin{array}{c}\text { As } \\
\text { underst } \\
\text { ood } \\
\text { from the } \\
\text { code; }\end{array}$ \\
\hline $\begin{array}{l}\text { External } \\
\text { audit }\end{array}$ & $\begin{array}{l}\text { Not mentioned } \\
\text { clearly in the code; }\end{array}$ & $\begin{array}{l}\frac{\text { Not }}{\text { mentioned }} \\
\frac{\text { clearly in the }}{\text { code; }}\end{array}$ & $\begin{array}{l}\text { IC committee, together } \\
\text { with EA, access the } \\
\text { accounting standard } \\
\text { appropriateness; }\end{array}$ & 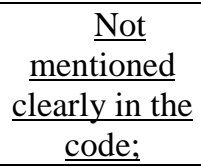 & \\
\hline $\begin{array}{l}\text { Disclosure } \\
\text { and } \\
\text { transparency }\end{array}$ & $\begin{array}{l}\text { Not mentioned } \\
\text { clearly in the code; }\end{array}$ & $\begin{array}{c}\frac{\text { Not }}{\text { mentioned }} \\
\frac{\text { clearly in the }}{\text { code; }}\end{array}$ & $\begin{array}{l}\text { MD ensure the correct } \\
\text { handling of confidential } \\
\text { information; }\end{array}$ & $\begin{array}{c}\frac{\text { Not }}{\text { mentioned }} \\
\frac{\text { clearly in the }}{\text { code; }}\end{array}$ & \\
\hline $\begin{array}{l}\text { Shareholder } \\
\text { s and Minority } \\
\text { Stockholder }\end{array}$ & $\begin{array}{c}\text { Directors } \\
\text { encourage } \\
\text { participation of } \\
\text { shareholders in GM; }\end{array}$ & $\begin{array}{c}\text { All } \\
\text { directors } \\
\text { attend GM; }\end{array}$ & $\begin{array}{c}\text { Board report to } \\
\text { shareholders at GM; }\end{array}$ & $\begin{array}{c}\frac{\text { Not }}{\text { mentioned }} \\
\frac{\text { clearly in the }}{\text { code; }}\end{array}$ & \\
\hline $\begin{array}{l}\text { Accountabili } \\
\text { ty }\end{array}$ & $\begin{array}{l}\text { Not mentioned } \\
\text { clearly in the code; }\end{array}$ & $\begin{array}{l}\frac{\text { Not }}{\text { mentioned }} \\
\frac{\text { clearly in the }}{\text { code; }}\end{array}$ & $\frac{\text { Not mentioned clearly in }}{\text { the code; }}$ & $\frac{\begin{array}{c}\text { Not } \\
\text { mentioned } \\
\text { clearly in the }\end{array}}{\text { code; }}$ & \\
\hline Leadership & $\begin{array}{l}\text { Strong executive } \\
\text { leadership; }\end{array}$ & $\begin{array}{l}\text { Through } \\
\text { the } \\
\text { commitment } \\
\text { of each } \\
\text { director; }\end{array}$ & Performed by board; & $\begin{array}{c}\frac{\text { Not }}{\text { mentioned }} \\
\text { clearly in the } \\
\underline{\text { code; }}\end{array}$ & $\begin{array}{c}\text { As } \\
\text { underst } \\
\text { ood } \\
\text { from the } \\
\text { code; }\end{array}$ \\
\hline Employee & $\begin{array}{l}\text { Not mentioned } \\
\text { clearly in the code; }\end{array}$ & $\begin{array}{l}\frac{\text { Not }}{\text { mentioned }} \\
\frac{\text { clearly in the }}{\text { code; }}\end{array}$ & $\frac{\text { Not mentioned clearly in }}{\text { the code; }}$ & $\begin{array}{l}\frac{\text { Not }}{\text { mentioned }} \\
\text { clearly in the } \\
\text { code; }\end{array}$ & \\
\hline $\begin{array}{l}\quad 3^{\text {rd }} \text { parties } \\
\text { and conflicts } \\
\text { of interests }\end{array}$ & & $\begin{array}{c}\text { Assess } \\
\text { potential } \\
\text { conflicts b.t } \\
\text { interests of } \\
\text { firm and of } \\
\text { controlling } \\
\text { shareholders; }\end{array}$ & $\begin{array}{l}\text { Special reference to } \\
\text { situations of conflicts of } \\
\text { interest; }\end{array}$ & & \\
\hline $\begin{array}{l}\text { Code of } \\
\text { ethics } \\
\text { (conduct) }\end{array}$ & $\begin{array}{l}\text { Not mentioned } \\
\text { clearly in the code; }\end{array}$ & $\frac{\frac{\text { Not }}{\text { mentioned }}}{\text { clearly in the }}$ & $\frac{\text { Not mentioned clearly in }}{\text { the code; }}$ & $\frac{\frac{\text { Not }}{\text { mentioned }}}{\frac{\text { clearly in the }}{\text { code; }}}$ & \\
\hline $\begin{array}{l}\text { Group and } \\
\text { subsidiaries }\end{array}$ & $\begin{array}{l}\text { Not mentioned } \\
\text { clearly in the code; }\end{array}$ & $\begin{array}{l}\frac{\text { Not }}{\text { mentioned }} \\
\frac{\text { clearly in the }}{\text { code; }}\end{array}$ & $\frac{\text { Not mentioned clearly in }}{\text { the code; }}$ & $\begin{array}{c}\frac{\text { Not }}{\text { mentioned }} \\
\frac{\text { clearly in the }}{\text { code; }}\end{array}$ & \\
\hline $\begin{array}{l}\text { CG Code } \\
\text { itself }\end{array}$ & $\begin{array}{l}\text { Not mentioned } \\
\text { clearly in the code; }\end{array}$ & $\begin{array}{l}\frac{\text { Not }}{\text { mentioned }} \\
\frac{\text { clearly in the }}{\text { code; }}\end{array}$ & $\frac{\text { Not mentioned clearly in }}{\text { the code; }}$ & $\begin{array}{c}\frac{\text { Not }}{\text { mentioned }} \\
\text { clearly in the } \\
\text { code; }\end{array}$ & \\
\hline Managemen & Not mentioned & Not & Not mentioned clearly in & Not & \\
\hline
\end{tabular}




\begin{tabular}{|c|c|c|c|c|c|}
\hline t system & clearly in the code; & $\frac{\frac{\text { mentioned }}{\text { clearly in the }}}{\text { code; }}$ & the code; & $\frac{\frac{\text { mentioned }}{\text { clearly in the }}}{\text { code; }}$ & \\
\hline Note & \multicolumn{5}{|c|}{$\begin{array}{l}\text { The underlined part is describing some more works needed to be done for relevant subjects and } \\
\text { parties. }\end{array}$} \\
\hline
\end{tabular}

Exhibit 4 - Evaluation of Austrian 2012 CG Principles

\begin{tabular}{|c|c|c|c|c|c|}
\hline $\begin{array}{l}\text { Subjects or } \\
\text { parties }\end{array}$ & $\begin{array}{l}\text { Main quality } \\
\text { factors }\end{array}$ & $\begin{array}{r}\text { Sub } \\
\text { quality } \\
\text { factors } \\
\end{array}$ & Responsibilities & Objectives & Note \\
\hline $\begin{array}{c}\text { Audit } \\
\text { committee }\end{array}$ & $\begin{array}{l}\text { Chairperson not a } \\
\text { MGT member in } \\
\text { past } 3 \text { years; at least } \\
2 \text { meetings per year; }\end{array}$ & $\begin{array}{l}1 \text { person } \\
\text { with practical } \\
\text { experience in } \\
\text { finance and } \\
\text { accounting; }\end{array}$ & $\begin{array}{l}\text { Select an auditor for F.S; } \\
\text { proposal for distribution of } \\
\text { profits; }\end{array}$ & $\begin{array}{l}\frac{\text { Not }}{\text { mentioned }} \\
\frac{\text { clearly in the }}{\text { code; }}\end{array}$ & \\
\hline $\begin{array}{l}\text { Nomination } \\
\text { committee }\end{array}$ & $\begin{array}{c}\text { Professional } \\
\text { qualification and a } \\
\text { balanced } \\
\text { composition of } \\
\text { expert knowledge; }\end{array}$ & $\begin{array}{l}\frac{\text { Not }}{\text { mentioned }} \\
\frac{\text { clearly in the }}{\text { code; }}\end{array}$ & $\frac{\text { Not mentioned clearly in }}{\text { the code; }}$ & $\begin{array}{l}\frac{\text { Not }}{\text { mentioned }} \\
\frac{\text { clearly in the }}{\text { code; }}\end{array}$ & \\
\hline $\begin{array}{l}\quad \text { Compensati } \\
\text { on, } \\
\text { Remuneration } \\
\text { committee }\end{array}$ & $\begin{array}{l}\text { At least } 1 \text { member } \\
\text { with remuneration } \\
\text { policy experience; }\end{array}$ & $\begin{array}{l}\text { Chairperso } \\
\mathrm{n} \text { is SB } \\
\text { chairperson; } \\
\text { may use } \\
\text { services of a } \\
\text { consultant; }\end{array}$ & $\begin{array}{l}\text { Remuneration of MGT board } \\
\text { based on work scope, duty } \\
\text { and personal performance; }\end{array}$ & 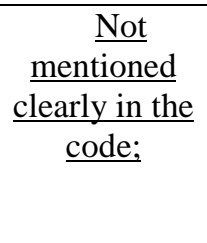 & \\
\hline $\begin{array}{l}\text { CEO } \\
\text { /President/MD }\end{array}$ & $\begin{array}{l}\text { Not mentioned } \\
\text { clearly in the code; }\end{array}$ & $\begin{array}{l}\frac{\text { Not }}{\text { mentioned }} \\
\frac{\text { clearly in the }}{\text { code; }}\end{array}$ & $\frac{\text { Not mentioned clearly in }}{\text { the code; }}$ & $\begin{array}{l}\frac{\text { Not }}{\text { mentioned }} \\
\frac{\text { clearly in the }}{\text { code; }}\end{array}$ & \\
\hline The Chair & $\begin{array}{r}\text { Not mentioned } \\
\text { clearly in the code; }\end{array}$ & $\frac{\underline{\text { Not }}}{\underline{\text { mentioned }}} \frac{\text { clearly in the }}{\text { code; }}$ & $\frac{\text { Not mentioned clearly in }}{\text { the code; }}$ & 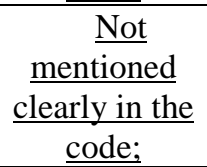 & \\
\hline $\begin{array}{l}\text { CEO and } \\
\text { The Chair } \\
\text { relationship }\end{array}$ & $\begin{array}{l}\text { Not mentioned } \\
\text { clearly in the code; }\end{array}$ & $\frac{\underline{\text { Not }}}{\text { mentioned }} \frac{\text { clearly in the }}{\text { code; }}$ & $\frac{\text { Not mentioned clearly in }}{\text { the code; }}$ & $\frac{\underline{\text { Not }}}{\text { mentioned }} \frac{\text { clearly in the }}{\text { code; }}$ & \\
\hline $\begin{array}{l}\text { Corporate } \\
\text { Secretary }\end{array}$ & $\begin{array}{l}\text { Not mentioned } \\
\text { clearly in the code; }\end{array}$ & $\frac{\underline{\text { Not }}}{\frac{\text { mentioned }}{\text { clearly in the }}}$ & $\frac{\text { Not mentioned clearly in }}{\text { the code; }}$ & $\frac{\underline{\text { Not }}}{\text { mentioned }} \frac{\text { clearly in the }}{\text { code; }}$ & \\
\hline $\begin{array}{l}\text { Compliance } \\
\text { officer }\end{array}$ & $\begin{array}{l}\text { Not mentioned } \\
\text { clearly in the code; }\end{array}$ & $\frac{\frac{\text { Not }}{\text { mentioned }}}{\frac{\text { clearly in the }}{\text { code; }}}$ & $\frac{\text { Not mentioned clearly in }}{\text { the code; }}$ & $\frac{\frac{\text { Not }}{\text { mentioned }}}{\text { clearly in the }}$ & \\
\hline $\begin{array}{l}\text { Board of } \\
\text { Directors }\end{array}$ & $\begin{array}{l}\text { Take into account } \\
\text { interests of } \\
\text { shareholders, } \\
\text { employee; }\end{array}$ & $\begin{array}{l}\text { Called mgt } \\
\text { board; SB } \\
\text { members } \\
\text { cannot be } \\
\text { MGT board } \\
\text { member; }\end{array}$ & $\begin{array}{l}\text { Agree strategic direction } \\
\text { with } \mathrm{SB} ;\end{array}$ & $\begin{array}{l}\frac{\underline{\text { Not }}}{\text { mentioned }} \\
\frac{\text { clearly in the }}{\text { code; }}\end{array}$ & \\
\hline $\begin{array}{l}\text { Executive/R } \\
\text { epresentative } \\
\text { director }\end{array}$ & $\frac{\text { Not mentioned }}{\text { clearly in the code; }}$ & $\begin{array}{l}\frac{\text { Not }}{\text { mentioned }} \\
\frac{\text { clearly in the }}{\text { code; }}\end{array}$ & $\frac{\text { Not mentioned clearly in }}{\text { the code; }}$ & $\begin{array}{c}\frac{\text { Not }}{\text { mentioned }} \\
\frac{\text { clearly in the }}{\text { code; }}\end{array}$ & \\
\hline $\begin{array}{c}\text { Non- } \\
\text { executive }\end{array}$ & $\begin{array}{r}\text { Not mentioned } \\
\text { clearly in the code; }\end{array}$ & $\underline{\underline{\text { Not }}}$ & $\begin{array}{l}\text { Not mentioned clearly in } \\
\text { the code; }\end{array}$ & $\underline{\underline{\text { Not }}}$ & \\
\hline
\end{tabular}


Network Intelligence Studies

Volume I, Issue 2, 2013

\begin{tabular}{|c|c|c|c|c|}
\hline director & & $\frac{\text { clearly in the }}{\text { code; }}$ & & $\frac{\text { clearly in the }}{\text { code; }}$ \\
\hline $\begin{array}{l}\text { Independent } \\
\text { director }\end{array}$ & $\begin{array}{l}\text { Not mentioned } \\
\text { clearly in the code; }\end{array}$ & $\begin{array}{l}\frac{\text { Not }}{\text { mentioned }} \\
\frac{\text { clearly in the }}{\text { code; }}\end{array}$ & $\frac{\text { Not mentioned clearly in }}{\text { the code; }}$ & $\begin{array}{l}\frac{\text { Not }}{\text { mentioned }} \\
\text { clearly in the } \\
\text { code; }\end{array}$ \\
\hline $\mathrm{CFO}$ & $\underline{\begin{array}{l}\text { Not mentioned } \\
\text { clearly in the code; }\end{array}}$ & $\begin{array}{l}\frac{\text { Not }}{\text { mentioned }} \\
\frac{\text { clearly in the }}{\text { code; }}\end{array}$ & $\frac{\text { Not mentioned clearly in }}{\underline{\text { the code; }}}$ & $\begin{array}{l}\frac{\text { Not }}{\text { mentioned }} \\
\frac{\text { clearly in the }}{\text { code; }}\end{array}$ \\
\hline $\begin{array}{l}\text { Managemen } \\
\mathrm{t} \text { team (Senior } \\
\text { Administration } \\
\text { ) }\end{array}$ & $\begin{array}{l}\text { Not mentioned } \\
\text { clearly in the code; }\end{array}$ & $\begin{array}{l}\text { provide SB } \\
\text { with } \\
\text { comprehensiv } \\
\text { e information } \\
\text { on risks and } \\
\text { bus. } \\
\text { development } \\
\text { (confidentialit } \\
\text { y); }\end{array}$ & $\begin{array}{l}\text { A balanced analysis of } \\
\text { risks and opportunities in a } \\
\text { takeover bid; }\end{array}$ & $\begin{array}{l}\frac{\text { Not }}{\text { mentioned }} \\
\frac{\text { clearly in the }}{\text { code; }}\end{array}$ \\
\hline $\begin{array}{l}\text { Supervisory } \\
\text { for the board } \\
\text { (SB) }\end{array}$ & $\begin{array}{l}\text { Open discussion } \\
\text { b.t mgt board (MB) } \\
\text { and SB; MB report } \\
\text { corruption to SB } \\
\text { once a year; }\end{array}$ & $\begin{array}{c}\text { New } \\
\text { candidate } \\
\text { disclosed } \\
\text { before GM; } \\
\text { docs prepared } \\
1 \text { week before } \\
\text { meeting; }\end{array}$ & $\begin{array}{c}\text { A balanced analysis of } \\
\text { risks and opportunities in a } \\
\text { takeover bid; be informed } \\
\text { cases with impact on profit or } \\
\text { liquidity; }\end{array}$ & $\begin{array}{c}\frac{\text { Not }}{\text { mentioned }} \\
\frac{\text { clearly in the }}{\text { code; }}\end{array}$ \\
\hline $\begin{array}{l}\text { Supervisory } \\
\text { for the } \\
\text { managers }\end{array}$ & $\begin{array}{l}\text { Not mentioned } \\
\text { clearly in the code; }\end{array}$ & $\begin{array}{l}\frac{\text { Not }}{\text { mentioned }} \\
\frac{\text { clearly in the }}{\text { code; }}\end{array}$ & Acts by SB; & $\begin{array}{l}\frac{\text { Not }}{\text { mentioned }} \\
\text { clearly in the } \\
\text { code; }\end{array}$ \\
\hline $\begin{array}{l}\text { Internal } \\
\text { control }\end{array}$ & $\begin{array}{l}\text { Not mentioned } \\
\text { clearly in the code; }\end{array}$ & $\begin{array}{l}\frac{\text { Not }}{\text { mentioned }} \\
\frac{\text { clearly in the }}{\text { code; }}\end{array}$ & $\begin{array}{c}\text { AC monitor the } \\
\text { effectiveness of the } \\
\text { company-wide IC system; }\end{array}$ & $\begin{array}{l}\frac{\text { Not }}{\text { mentioned }} \\
\frac{\text { clearly in the }}{\text { code; }}\end{array}$ \\
\hline $\begin{array}{c}\text { Internal or } \\
\text { statutory audit }\end{array}$ & $\begin{array}{l}\text { Not mentioned } \\
\text { clearly in the code; }\end{array}$ & $\begin{array}{c}\text { Once a } \\
\text { year, report } \\
\text { on audit plan; }\end{array}$ & $\begin{array}{l}\text { Can be conducted by a } \\
\text { separate staff unit; }\end{array}$ & $\begin{array}{c}\frac{\text { Not }}{\text { mentioned }} \\
\text { clearly in the } \\
\text { code; }\end{array}$ \\
\hline $\begin{array}{l}\text { External } \\
\text { audit }\end{array}$ & $\begin{array}{c}\text { AC exchange } \\
\text { views with EA at } \\
\text { meeting w/o } \\
\text { presence of MGT } \\
\text { board members; }\end{array}$ & $\begin{array}{l}\text { Independe } \\
\text { nt; }\end{array}$ & $\begin{array}{l}\text { Any additional business } \\
\text { relationships to be audited; } \\
\text { send audit report to SB; }\end{array}$ & $\begin{array}{c}\frac{\text { Not }}{\text { mentioned }} \\
\frac{\underline{\text { clearly in the }}}{\text { code; }}\end{array}$ \\
\hline $\begin{array}{l}\text { Disclosure } \\
\text { and } \\
\text { transparency }\end{array}$ & $\begin{array}{l}\text { Not mentioned } \\
\text { clearly in the code; }\end{array}$ & $\begin{array}{l}\text { Appoint a } \\
\text { contact } \\
\text { person for } \\
\text { investor } \\
\text { relations; }\end{array}$ & $\begin{array}{l}\text { Disclose any new facts that } \\
\text { it communicates to financial } \\
\text { analysts to shareholders; }\end{array}$ & $\begin{array}{c}\frac{\text { Not }}{\text { mentioned }} \\
\frac{\underline{\text { clearly in the }}}{\text { code; }}\end{array}$ \\
\hline $\begin{array}{l}\text { Shareholder } \\
\text { s and Minority } \\
\text { Stockholder }\end{array}$ & $\begin{array}{l}\text { Treated equally } \\
\text { under the same } \\
\text { conditions; }\end{array}$ & $\begin{array}{l}\text { Resolution } \\
\text { passed at Gm } \\
\text { disclosed on } \\
\text { website; }\end{array}$ & $\begin{array}{l}\text { When appointing SB GM } \\
\text { consider balance of structure } \\
\text { and business; }\end{array}$ & $\begin{array}{l}\frac{\text { Not }}{\text { mentioned }} \\
\frac{\text { clearly in the }}{\text { code; }}\end{array}$ \\
\hline $\begin{array}{l}\text { Accountabili } \\
\text { ty }\end{array}$ & $\begin{array}{l}\text { Not mentioned } \\
\text { clearly in the code; }\end{array}$ & $\begin{array}{l}\frac{\text { Not }}{\text { mentioned }} \\
\frac{\text { clearly in the }}{\text { code; }}\end{array}$ & $\begin{array}{l}\text { Firm prepare consolidated } \\
\text { F.S in accordance with IFRS; } \\
\text { IAS34; }\end{array}$ & $\begin{array}{l}\frac{\text { Not }}{\text { mentioned }} \\
\text { clearly in the } \\
\text { code; }\end{array}$ \\
\hline Leadership & $\begin{array}{l}\text { Not mentioned } \\
\text { clearly in the code; }\end{array}$ & $\begin{array}{l}\text { SB meets } \\
\text { at least } 4 \\
\text { times a year; } \\
\text { SB decides }\end{array}$ & Act by SB; & $\begin{array}{l}\frac{\text { Not }}{\text { mentioned }} \\
\frac{\text { clearly in the }}{\text { code; }}\end{array}$ \\
\hline
\end{tabular}


Network Intelligence Studies

Volume I, Issue 2, 2013

\begin{tabular}{|c|c|c|c|c|c|}
\hline & & $\begin{array}{l}\text { the approval } \\
\text { of F.S; }\end{array}$ & & & \\
\hline Employee & $\begin{array}{l}\text { Not mentioned } \\
\text { clearly in the code; }\end{array}$ & $\begin{array}{l}\text { Employee' } \\
\text { s } \\
\text { representative } \\
\text { s Have rights } \\
\text { to receive } \\
\text { information; }\end{array}$ & $\begin{array}{c}\text { Employee's } \\
\text { representatives exercise } \\
\text { functions on honorary basis; }\end{array}$ & $\begin{array}{c}\frac{\text { Not }}{\text { mentioned }} \\
\frac{\text { clearly in the }}{\text { code; }}\end{array}$ & \\
\hline $\begin{array}{l}3^{\text {rd }} \text { parties } \\
\text { and conflicts } \\
\text { of interests }\end{array}$ & $\begin{array}{c}\text { If SB member } \\
\text { find him/herself a } \\
\text { conflict of interest, } \\
\text { disclose to SB } \\
\text { chairperson; } \\
\text { Chairperson disclose } \\
\text { to his/her deputy; }\end{array}$ & $\begin{array}{c}\text { MGT } \\
\text { board } \\
\text { member } \\
\text { inform SB } \\
\text { transactions } \\
\text { of group } \\
\text { companies } \\
\text { and conflicts; }\end{array}$ & $\begin{array}{l}\text { MGT board take decisions } \\
\text { w/o being influenced by } \\
\text { controlling shareholders; }\end{array}$ & $\frac{\begin{array}{c}\text { Not } \\
\text { mentioned } \\
\text { clearly in the }\end{array}}{\underline{\text { code; }}}$ & \\
\hline $\begin{array}{l}\text { Code of } \\
\text { ethics } \\
\text { (conduct) }\end{array}$ & $\begin{array}{l}\text { Not mentioned } \\
\text { clearly in the code; }\end{array}$ & $\begin{array}{c}\frac{\text { Not }}{\text { mentioned }} \\
\frac{\text { clearly in the }}{\text { code; }}\end{array}$ & $\frac{\text { Not mentioned clearly in }}{\text { the code; }}$ & $\begin{array}{c}\frac{\text { Not }}{\text { mentioned }} \\
\frac{\text { clearly in the }}{\text { code; }}\end{array}$ & \\
\hline $\begin{array}{l}\text { Group and } \\
\text { subsidiaries }\end{array}$ & $\begin{array}{l}\text { Not mentioned } \\
\text { clearly in the code; }\end{array}$ & $\begin{array}{c}\frac{\text { Not }}{\text { mentioned }} \\
\frac{\text { clearly in the }}{\text { code; }}\end{array}$ & $\frac{\text { Not mentioned clearly in }}{\text { the code; }}$ & $\frac{\begin{array}{c}\text { Not } \\
\text { mentioned }\end{array}}{\text { clearly in the }}$ & \\
\hline $\begin{array}{l}\text { CG Code } \\
\text { itself }\end{array}$ & $\begin{array}{c}\text { Not require } \\
\text { disclose business } \\
\text { secrets; }\end{array}$ & $\begin{array}{r}\text { Reviewed } \\
\text { once a year; }\end{array}$ & $\begin{array}{l}\text { Set a system of MGT and } \\
\text { control of companies; }\end{array}$ & $\begin{array}{l}\text { Increase } \\
\text { transparency for } \\
\text { all stakeholders; }\end{array}$ & \\
\hline $\begin{array}{l}\text { Managemen } \\
\text { t system }\end{array}$ & $\begin{array}{l}\text { Describe in mgt } \\
\text { report the most } \\
\text { important features } \\
\text { of IC and RM; }\end{array}$ & $\begin{array}{c}\text { CG report } \\
\text { mentions } \\
\text { measures } \\
\text { taken to } \\
\text { promote } \\
\text { women to } \\
\text { MGT board } \\
\text { and SB, top } \\
\text { MGT } \\
\text { positions; }\end{array}$ & $\begin{array}{l}\text { The firm has a CG report } \\
\text { which mentions the } \\
\text { composition and working } \\
\text { procedure of MGT board; }\end{array}$ & $\begin{array}{c}\frac{\text { Not }}{\text { mentioned }} \\
\text { clearly in the } \\
\text { code; }\end{array}$ & \\
\hline Note & \multicolumn{5}{|c|}{$\begin{array}{c}\text { The underlined part is describing some more works needed to be done for relevant subjects and } \\
\text { parties. }\end{array}$} \\
\hline
\end{tabular}


Table 1 - A so-called Limited Western European CG representative standards

\section{Subjects or parties}

Audit committee

\section{CEO and The Chair}

Corporate Secretary

Compliance officer

Board of Directors

Independent director

Supervisory board to the Management

Supervisory to the Board of Directors

Internal control

Internal audit

External audit

Disclosure and

transparency

Shareholders

The corporation as a whole entity Main quality factors

AC discuss significant financial reporting issues with EA and executive

MGT; meet at least 4 times a year;

twice a year meet IA and EA to discuss weakness of IC;

Consider positive and negative aspects if board considered the former CEO as chairman;

Ensure good information flow within board, committee, executive MGT and NEDs;

A compliance committee installed, or a high level compliance officer appointed;

No individual or group dominate board's decision making; organizing meetings using internet, video or telephone;

Independency of judgement and objectivity in making board decisions;

SB ensures individuals involved in daily MGT are of professional, integrity and social and moral; Meet regularly and retain effective control over the firm

A framework of IC set by executive MGT approved by board; AC review IA work program;

Examine with AC safety measures taken to decrease risks;

SB ensures timely and accurate disclosure;

Controlling shareholders can appoint representatives to the board; Board ensures its obligations to shareholders are met;

Has CG code with provisions and guidelines on how the firm implements the provisions of the code;
Sub quality factors

New AC members provided with IC,

$\mathrm{RM}$, operational, financial, accounting and auditing information;

Chairman consults with CEO setting board meeting agenda;

Advise board on all governance matters; regularly report to board;

Can be company lawyer;

Ensure accuracy and completeness of CG charter and CG statement;

Not an executive member of board;

SB ensures MGT take follow-up actions on supervisory recommendations;

Committee of SB comprises a majority of unrelated supervisory directors; the engagement of an outside adviser;

Main risks identified and managed;

AC recommends

appointment/removal head of IA

Comment on the true and fair view of the firm assets and liabilities, financial positions; report AC key matters of FS; Executive MGT prepare firm disclosure of F.S;

Controlling shareholders can appoint representatives to the board;

CG charter on firm website and CG statement on annual report;

Table 2 - A relatively Good Corporate Governance standards

\begin{tabular}{|c|c|c|}
\hline Subjects or parties & Main quality factors & Sub quality factors \\
\hline udit committee & $\begin{array}{l}\text { Monitor the work of the auditor; } \\
\text { audit any consolidated F.S; }\end{array}$ & $\begin{array}{l}\text { Set up by SB; monitor the preparation } \\
\text { of accounting procedures; }\end{array}$ \\
\hline EO and The Chair & $\begin{array}{l}\text { Included in Board; board delegates } \\
\text { powers to chairman; }\end{array}$ & MD identify main risks; \\
\hline orporate Secretary & $\begin{array}{l}\text { N/A (for further research and } \\
\text { implementation) }\end{array}$ & $\begin{array}{l}\text { N/A (for further research and } \\
\text { implementation) }\end{array}$ \\
\hline ompliance officer & $\begin{array}{l}\text { N/A (for further research and } \\
\text { implementation) }\end{array}$ & $\begin{array}{l}\text { N/A (for further research and } \\
\text { implementation) }\end{array}$ \\
\hline $\begin{array}{l}\text { oard of Directors (MGT } \\
\text { oard) }\end{array}$ & $\begin{array}{l}\text { Take appropriate measures to secure } \\
\text { compliance with laws; chairperson of }\end{array}$ & $\begin{array}{l}\text { Fundamental decisions on goals or } \\
\text { strategy reached by all MGT board; }\end{array}$ \\
\hline
\end{tabular}




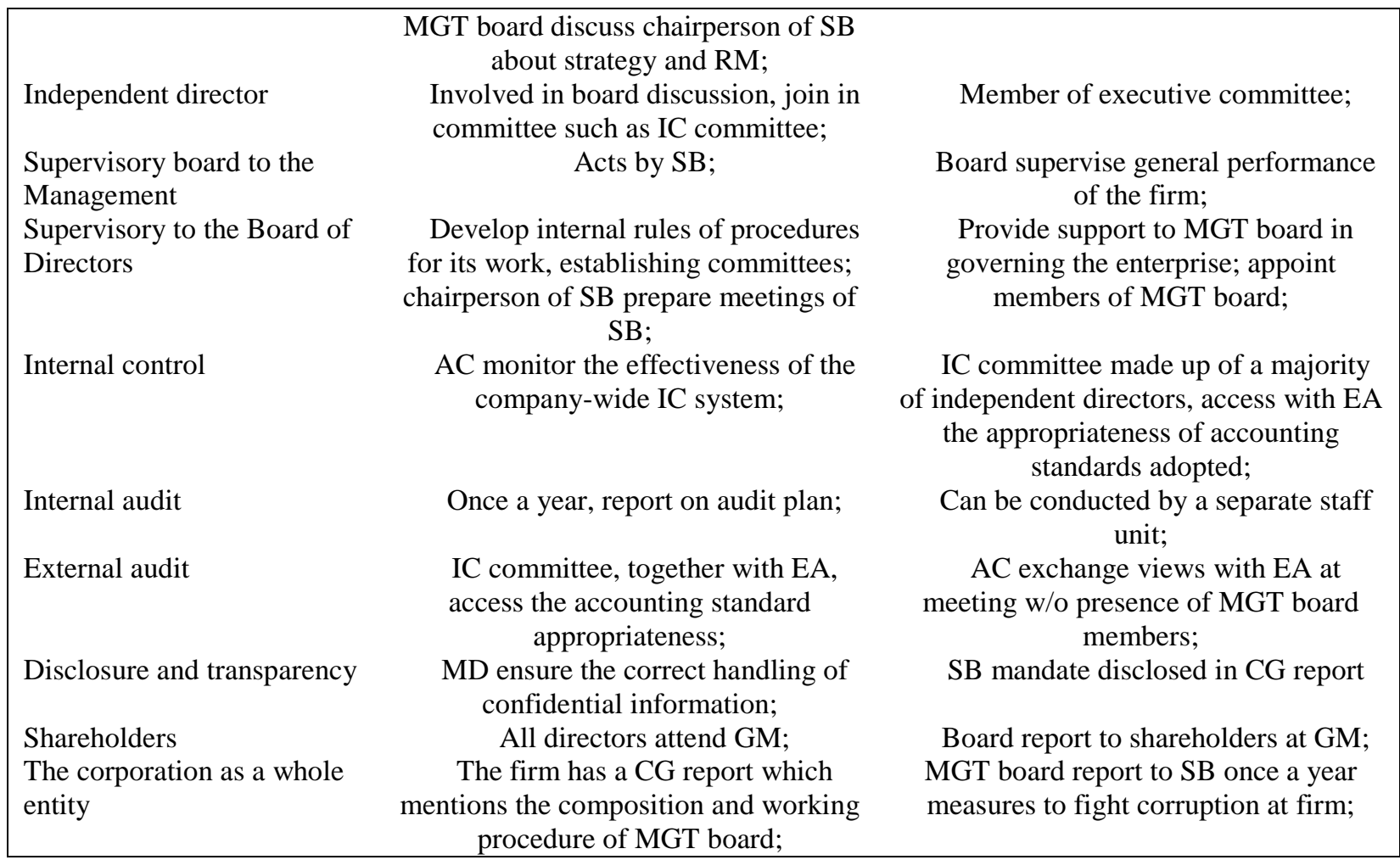

Table 3 - The Comparative Western European Corporate Governance standards

\begin{tabular}{|c|c|c|}
\hline Subjects or parties & Main quality factors & Sub quality factors \\
\hline Audit committee & $\begin{array}{c}\text { AC discuss significant } \\
\text { financial reporting issues with } \\
\text { EA and executive MGT; meet } \\
\text { at least } 4 \text { times a year; twice a } \\
\text { year meet IA and EA to } \\
\text { discuss weakness of IC; }\end{array}$ & $\begin{array}{l}\text { Monitor the work of the auditor; audit any } \\
\text { consolidated F.S; }\end{array}$ \\
\hline Nominating committee & $\begin{array}{l}\text { Professional qualification } \\
\text { and a balanced composition of } \\
\text { expert knowledge; }\end{array}$ & $\begin{array}{l}\text { Assist board on nomination and planning of } \\
\text { CEO; majority comprises independent NEDs; }\end{array}$ \\
\hline Numeration or & Remuneration of MGT & Meet at least twice a year; \\
\hline Compensation Committee & $\begin{array}{l}\text { board based on work scope, } \\
\text { duty and personal } \\
\text { performance; }\end{array}$ & \\
\hline CEO and The Chair & $\begin{array}{l}\text { Consider positive and } \\
\text { negative aspects if board } \\
\text { considered the former CEO as } \\
\text { chairman; }\end{array}$ & $\begin{array}{c}\text { The Chair call the board meeting, set agenda; } \\
\text { coordinate activities of BD; ensure all directors } \\
\text { make a knowledgeable contribution to board } \\
\text { discussion; }\end{array}$ \\
\hline $\mathrm{CFO}$ & $\begin{array}{l}\text { AC decides when } \mathrm{CFO} \text {, } \\
\text { CEO attend meeting; }\end{array}$ & N/A (for further research and implementation) \\
\hline Corporate Secretary & $\begin{array}{l}\text { Board describes roles and } \\
\text { tasks of secretary; }\end{array}$ & $\begin{array}{l}\text { Ensure good information flow within board, } \\
\text { committee, executive MGT and NEDs; }\end{array}$ \\
\hline Compliance officer & $\begin{array}{l}\text { A compliance committee } \\
\text { installed, or a high level } \\
\text { compliance officer appointed; }\end{array}$ & N/A (for further research and implementation) \\
\hline $\begin{array}{l}\text { Board of Directors or } \\
\text { Management Board }\end{array}$ & $\begin{array}{c}\text { Check the adequacy of } \\
\text { organizational and } \\
\text { administrative structures set } \\
\text { by MD; }\end{array}$ & $\begin{array}{l}\text { No individual or group dominate board's } \\
\text { decision making; organizing meetings using } \\
\text { internet, video or telephone; }\end{array}$ \\
\hline Independent director & $\begin{array}{c}\text { Involved in board } \\
\text { discussion, join in committee }\end{array}$ & $\begin{array}{l}\text { Independency of judgement and objectivity in } \\
\text { making board decisions; }\end{array}$ \\
\hline
\end{tabular}


Network Intelligence Studies

Volume I, Issue 2, 2013

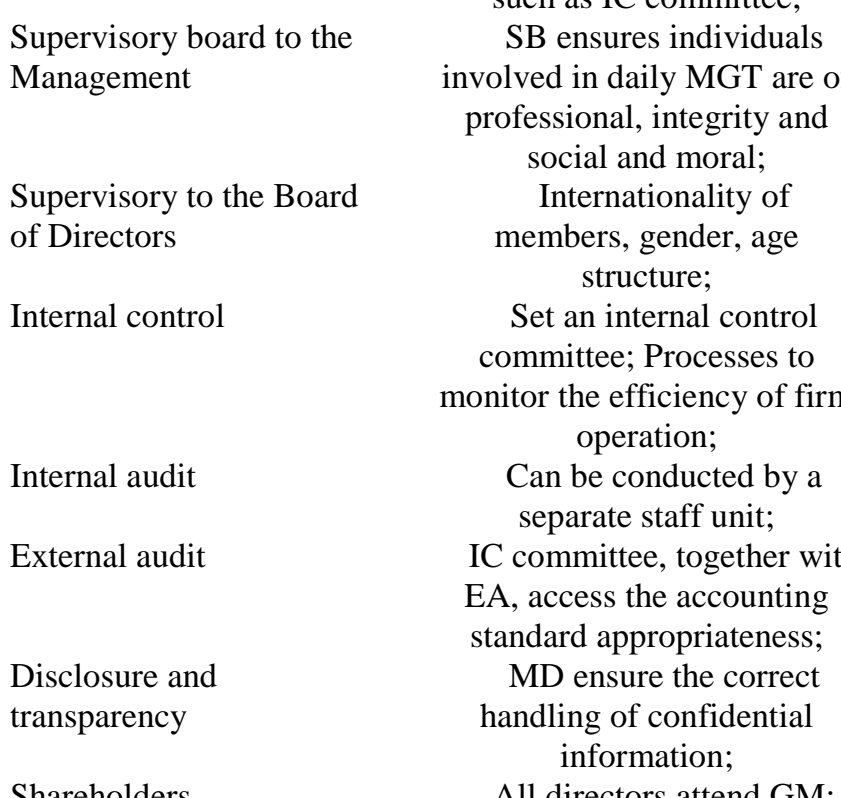

Shareholders

Stakeholders

Accountability

Leadership

Employee

$3^{\text {rd }}$ parties and conflicts of interests

The corporation as a whole entity

The Code
All directors attend GM;

CG Code designed to increase transparency for all stakeholders;

Firm prepare consolidated

F.S in accordance with IFRS;

Chairman responsible for leadership of board;

Employee's representatives have rights to receive information;

Assess potential conflicts b.t interests of firm and of controlling shareholders;

Fundamental decisions on goals or strategy reached by all MGT board;

Help determines firm goals; one-tier board model; has principles, provisions and guidelines;
SB ensures MGT take follow-up actions on supervisory recommendations;

Meet regularly and retain effective control over the firm

A framework of IC set by executive MGT approved by board;

AC review IA work program; Once a year, report on audit plan;

Comment on the true and fair view of the firm assets and liabilities, financial positions; report AC key matters of FS;

Executive MGT prepare firm disclosure of F.S

Controlling shareholders can appoint representatives to the board; Board ensures its

obligations to shareholders are met;

MGT board responsible for communication tasks affecting firm image perceived by stakeholders;

Executive MGT accountable to board for the discharge of its duties;

Board provides entrepreneur leadership; strong executive leadership;

At GM, directors answer questions which do not prejudice firm, employee, shareholders;

Each board member avoid direct and indirect conflicts of interest;

CG charter on firm website and CG statement on annual report;

Ensure leadership, integrity and transparency in the decision making process;

(Note: source are based on corporate governance standards of group $\langle D .1\rangle$ and $\langle D .2\rangle$ and the appraisal of these standards) 